\title{
Analisis Pengaruh Kinerja dan Kondisi Makroekonomi terhadap Penyaluran Pembiayaan Modal Kerja dan Investasi BPRS di Indonesia (Periode: 2011-2015)
}

\section{Effect Analysis of IRB Performance and Macroeconomic Conditions on The Distribution of IRB Working Capital and Investment Financing in Indonesia (Period: 2011-2015)}

\author{
Arno Nugroho ${ }^{1}$, Muhammad Findi Alexandi ${ }^{2}$, Widyastutik $^{3}$ \\ ${ }^{1}$ Departemen Ilmu Ekonomi Syariah, Institut Pertanian Bogor 16680, \\ email: arnonugroho3@gmail.com \\ ${ }^{2}$ Departemen Ilmu Ekonomi, Institut Pertanian Bogor 16680, email: muhammadfindi73@yahoo.com \\ ${ }^{3}$ Departemen Ilmu Ekonomi, Institut Pertanian Bogor 16680, email: widyastutik_ipb@yahoo.com
}

\begin{abstract}
Sharia banking operational activities to encourage the real sector is to provide financing. The Islamic Rural Bank (IRB) conducts financing for working capital and investment as it can increase economic growth in Indonesia. The purpose of this study is to analyze and compare the effect of performance IRB and macroeconomic conditions on the distribution of IRB working capital and investment financing in Indonesia from 2011 to 2015 using Vector Error Correction Model (VECM) research method with monthly data from 2011 to 2015. From the results of VECM estimates, it will be seen the response of working capital and investment financing to shocks arising from the performance IRB and macroeconomic conditions and also the contribution of each of each variable used in the study. The results of this study indicate that the effect of performance IRB and macroeconomic conditions on the working capital financing of IRB in Indonesia, have positive and significant effect on DPK, FDR, ERDPK, inflation and IPI variables have negative and significant effect on ROA, NPF, $B O P O$, and BI rate, and no significant effect on CAR and ERP variables. The financing of BPRS investment in Indonesia, which has positive and significant effect on the DPK, CAR, ROA, FDR, BI rate, and IPI variables, has a negative and significant effect on NPF, BOPO, ERP, ERDPK, and inflation variables.
\end{abstract}

Keywords: investment, IRB performance, macroeconomic conditions, working capital, VECM

\begin{abstract}
Abstrak. Bentuk kegiatan operasional perbankan syariah untuk mendorong sektor riil yaitu memberikan pembiayaan. Bank Pembiayaan Rakyat Syariah (BPRS) melakukan pembiayaan untuk modal kerja dan investasi karena dapat meningkatkan pertumbuhan ekonomi di Indonesia. Tujuan penelitian ini adalah menganalisis dan membandingkan pengaruh kinerja BPRS dan kondisi makroekonomi terhadap penyaluran pembiayaan modal kerja dan investasi BPRS di Indonesia dari tahun 2011 sampai 2015 dengan menggunakan metode penelitian Vector Error Correction Model (VECM) dengan data bulanan periode 2011 hingga 2015. Setelah mendapatkan hasil estimasi VECM maka akan dilihat respon pembiayaan modal kerja dan investasi terhadap guncangan yang timbul dari kinerja BPRS dan kondisi makroekonomi serta melihat kontribusi masing-masing setiap variabel yang digunakan dalam penelitian. Hasil penelitian ini menunjukkan bahwa pengaruh variabel kinerja BPRS dan kondisi makroekonomi terhadap pembiayaan modal kerja BPRS di Indonesia, yaitu berpengaruh positif dan signifikan pada variabel DPK, FDR, ERDPK, inflasi, dan IPI, berpengaruh negatif dan signifikan pada variabel ROA, NPF, BOPO, dan BI rate, dan tidak berpengaruh signifikan pada variabel CAR dan ERP. Pembiayaan investasi BPRS di Indonesia, yaitu berpengaruh positif dan signifikan pada variabel DPK, CAR, ROA, FDR, BI rate, dan IPI, berpengaruh negatif dan signifikan pada variabel NPF, BOPO, ERP, ERDPK, dan inflasi.
\end{abstract}

Kata kunci: investasi, kinerja BPRS, kondisi makroekonomi, modal kerja, VECM

\section{PENDAHULUAN}

Perbankan memiliki peran penting dalam rangka pembangunan ekonomi suatu negara. Peran penting tersebut sehubungan dengan fungsi bank sebagai lembaga intermediasi yang menyerap 
dana dari masyarakat surplus ekonomi serta menyalurkannya ke masyarakat yang membutuhkan (Soemitra, 2010). Pertumbuhan ekonomi memiliki korelasi dengan instrumen keuangan yang diberikan oleh sektor perbankan. Dalam rangka mencapai pertumbuhan ekonomi pada tingkat yang diinginkan maka kegiatan operasional yang dilakukan perbankan harus mendorong dunia usaha. Indonesia merupakan negara yang menganut sistem perbankan ganda (dual banking system), yaitu perbankan konvensional dan perbankan syariah (Machmud \& Rukmana, 2010).

Menurut Kashmir (2008) perbedaan antara bank konvensional dengan bank syariah, antara lain penyaluran dana yang dihimpun perbankan syariah dari nasabah digunakan untuk kepentingan di sektor-sektor riil serta melihat aspek halal-haramnya, sedangkan pada perbankan konvensional tidak melihat aspek kehalalan. Persentase bunga pada perbankan konvensional didasarkan pada modal yang ada sedangkan bagi hasil pada perbankan syariah didasarkan pada keuntungan yang telah dicapai. Sistem perbankan syariah tidak mempunyai sistem kredit yang disertai dengan sistem bunga tersebut. Bank syariah menggunakan sistem pembiayaan disertai dengan sistem bagi hasil sebagai imbalannya.

Berdasarkan Al Quran surat Ali Imran ayat 130 tentang larangan riba yang artinya, "Hai orangorang yang beriman, janganlah kamu memakan riba dengan berlipat ganda dan bertakwalah kamu kepada Allah supaya kamu mendapat keberuntungan". Ayat ini memiliki makna bahwa memakan riba atau seringkali disebut bunga dalam dunia perbankan adalah salah satu perbuatan dosa yang dilarang oleh Allah SWT, sehingga perbankan syariah merupakan solusi tepat agar terhindar dari bahaya riba. Selain itu, Al Quran juga menjelaskan dalam surat Al-Hasyr ayat 7 yang artinya, "Apa saja harta rampasan (fai'i) yang diberikan Allah kepada Rasulnya, (dari harta benda) yang berasal dari penduduk kota-kota maka adalah untuk Allah, untuk Rasul, kaum kerabat, anak-anak yatim, orang-orang miskin dan orang-orang yang dalam perjalanan, sepaya harta itu jangan beredar diantara orang-orang kaya saja diantara kamu. Apa yang diberikan Rasul kepadamu maka terimalah, dan apa yang dilarangnya bagimu, maka tinggalkanlah. Dan bertaqwalah kepada Allah, sesungguhnya Allah amat keras hukumannya". Ayat ini merupakan perintah Allah SWT agar harta-harta yang ada dimuka bumi tidak beredar diantara orang-orang kaya saja, sehingga pembiayaan merupakan alternatif agar harta-harta yang ada tidak tertimbun dan dapat tersebar merata.

Perkembangan bank syariah di Indonesia tumbuh dengan pesat, hal ini dapat dilihat dari banyaknya bank syariah yang muncul dan bersaing dengan bank konvensional yang telah beroperasi dan dikenal lebih dahulu oleh masyarakat Indonesia. Kehadiran bank syariah tidak hanya untuk memberi alternatif perbankan non riba bagi masyarakat, namun juga untuk mengembangkan sektor riil. Hal ini sejalan dengan penjelasan mengenai bank syariah yang merupakan lembaga keuangan yang berfungsi memperlancar mekanisme ekonomi di sektor riil melalui kegiatan usahanya berdasarkan prinsip syariah (Sambo \& Abdulkadir, 2015).

Bentuk kegiatan operasional perbankan syariah untuk mendorong dunia usaha yaitu memberikan pembiayaan. Pembiayaan yang dilakukan oleh perbankan syariah selain disalurkan ke sektorsektor riil juga disalurkan untuk memenuhi peningkatan produksi suatu usaha baik secara kuantitatif maupun kualitatif dalam bentuk modal kerja. Selain pembiayaan modal kerja, perbankan syariah juga menyalurkannya pada pembiayaan investasi. Menurut Mankiw (2006), berdasarkan teori makroekonomi persediaan modal kerja meningkat karena peningkatan investasi. Peningkatan investasi pada sektor riil juga akan mendorong dan meningkatkan pertumbuhan ekonomi. Pembiayaan pada modal kerja dan investasi berguna bagi masyarakat yang sedang melakukan usaha untuk meningkatkan produksinya, misalnya persediaan bahan baku, persediaan bahan jadi, biaya operasional sehari-hari dan lain-lain sehingga dapat menjalankan usahanya dengan normal dan lancar (Fazzari \& Petersen, 1993). 
Peningkatan investasi dan tambahan modal kerja yang didapat dari perbankan syariah akan meningkatkan kapasitas produksinya kemudian berdampak pada peningkatan perluasan usaha yang akan menciptakan lapangan kerja baru. Dampak lainnya adalah adanya lapangan kerja baru yang tercipta akan menekan angka pengangguran. Jumlah tenaga kerja yang terus bertambah akan meningkatkan pendapatan per kapita, meningkatkan daya beli masyarakat dan meningkatkan pendapatan nasional (Tanjung et al., 2007).

Bagian dari lembaga keuangan syariah dibidang perbankan yang menyediakan layanan pembiayaan selain BUS dan UUS yaitu Bank Pembiayaan Rakyat Syariah (BPRS). BPRS skalanya lebih kecil dibanding BUS dan UUS, akan tetapi jumlahnya lebih banyak. Ini mengindikasikan bahwa lembaga keuangan syariah berperan penting dalam kehidupan masyarakat terutama di sektor UMKM dalam mengatasi masalah pembiayaan. Berdasarkan data Statistik Perbankan Syariah Otoritas Jasa Keuangan (SPS-OJK) menunjukkan bahwa jumlah pembiayaan dilakukan BPRS dari tahun 2011 hingga tahun 2015 terus bertambah pada setiap tahunnya. Pembiayaan BPRS berdasarkan sektor ekonomi meliputi sektor pertanian, kehutanan, dan sarana pertanian, pertambangan, perindustrian, listrik, gas dan air, konstruksi, perdagangan, restoran dan hotel, pengangkutan, pergudangan, dan komunikasi, jasa dunia usaha, jasa sosial, sektor-sektor lainnya. Tidak hanya itu berdasarkan jenis penggunaanya terdiri dari modal kerja, investasi, dan konsumsi. Pembiayaan berdasarkan jenis penggunaannya ini jumlahnnya selalu meningkat setiap tahunnya. Hal ini dapat dilihat pada Tabel 1.

Tabel 1 Jumlah pembiayaan berdasarkan jenis penggunaannya pada BPRS tahun 2011-2015 (miliar rupiah)

\begin{tabular}{crrrrr}
\hline & 2011 & 2012 & 2013 & 2014 & 2015 \\
\hline Modal Kerja & 1470 & 1836 & 2206 & 2348 & 2559 \\
Investasi & 276 & 465 & 612 & 893 & 1109 \\
Konsumsi & 930 & 1252 & 1615 & 1763 & 2097 \\
Total & $\mathbf{2 6 7 6}$ & $\mathbf{3 5 5 3}$ & $\mathbf{4 4 3 3}$ & $\mathbf{5 0 0 5}$ & $\mathbf{5 7 6 5}$ \\
\hline
\end{tabular}

Sumber: Otoritas Jasa Keuangan (2015), diolah

Berdasarkan Tabel 1 diketahui bahwa pembiayaan berdasarkan jenis penggunaannya terdiri dari modal kerja, investasi, dan konsumsi. Total pembiayaan berdasarkan jenis penggunaannya pada tahun 2011 sebesar 2676 miliar rupiah hingga pada tahun 2015 mencapai 5765 miliar rupiah. Pada pembiayaan modal kerja dan investasi juga terus meningkat dari tahun 2011 sampai 2015, akan tetapi jumlah nominalnya pembiayaan modal kerja lebih besar yaitu dari 1470 miliar rupiah hingga 2559 miliar rupiah, sedangkan pembiayaan investasi hanya 276 miliar rupiah hingga 1109 miliar rupiah. Meskipun jumlah pembiayaan yang dilakukan BPRS untuk pembiayaan produktif yaitu modal kerja dan investasi setiap tahunnya meningkat, tetapi persentase pembiayaan modal kerja dan investasi terhadap keseluruhan tiap tahunnya terjadi perbedaan. Kondisi ini dapat dilihat pada Tabel 2.

Tabel 2 Persentase pembiayaan berdasarkan jenis penggunaannya pada BPRS tahun 2011-2015 (persen)

\begin{tabular}{cccccc}
\hline & 2011 & 2012 & 2013 & 2014 & 2015 \\
\hline Modal Kerja & 54.9 & 51.7 & 49.8 & 46.9 & 44.4 \\
Investasi & 10.3 & 13.1 & 13.8 & 17.9 & 19.2 \\
Konsumsi & 34.8 & 35.2 & 36.4 & 35.2 & 36.4 \\
Total & 100 & 100 & 100 & 100 & 100 \\
\hline
\end{tabular}

Sumber: Otoritas Jasa Keuangan (2015), diolah 
Berdasarkan Tabel 2 diketahui bahwa persentase pembiayaan berdasarkan jenis penggunaannya yang dilakukan oleh BPRS didominasi oleh modal kerja dibandingkan pembiayaan untuk investasi dan konsumsi. Walaupun modal kerja mendominasi, tetapi persentase setiap tahunnya mengalami penurunan. Persentase pembiayaan modal kerja pada tahun 2011 sebesar 54.9 persen terus menurun hingga tahun 2015 sebesar 44.4 persen, sedangkan pembiayaan investasi yang dilakukan BPRS persentasenya paling kecil, akan tetapi terus meningkat dari 10.3 persen di tahun 2011 sampai 19.2 persen pada tahun 2015 dan persentase pembiayaan konsumsi mengalami fluktuasi pada periode 2011 sampa 2015. Naik turunnya pembiayaan modal kerja dan investasi dipengaruhi oleh berbagai faktor. Beberapa studi diantaranya Beik dan Aprianti (2013) menunjukkan bahwa indikator-indikator makroekonomi maupun kinerja internal memengaruhi pembiayaan. Terkait dengan latar belakang tersebut relevan dilakukan penelitian dengan judul "Analisis Pengaruh Kinerja BPRS dan Kondisi Makroekonomi Terhadap Penyaluran Pembiayaan Modal Kerja dan Investasi BPRS di Indonesia".

Bank Pembiayaan Rakyat Syariah (BPRS) dalam melakukan pembiayaan terdiri dari dua macam, yaitu pembiayaan produktif dan pembiayaan konsumtif. Pembiayaan yang sifatnya produktif pada latar belakang sudah dijelaskan bahwa berdasarkan jenis penggunaanya yaitu pembiayaan modal kerja dan investasi. Total pembiayaan modal kerja dan investasi yang dilakukan BPRS di Indonesia selalu meningkat setiap tahunnya. Peningkatan ini hanya diikuti oleh rasio pembiayaan investasi terhadap total pembiayaan yang dilakukan walaupun rasionya paling sedikit. Pada rasio pembiayaan modal kerja terhadap total pembiayaan BPRS yang merupakan prioritas BPRS itu sendiri mengalami penurunan pada setiap periode. Perkembangan rasio pembiayaan produktif ini dapat dilihat pada Gambar 1.

Pada Gambar 1 menunjukkan bahwa rasio pembiayaan modal kerja dan investasi terhadap total pembiayan mempunyai tren yang berbeda. Pembiayaan modal kerja mempunyai tren negatif, sedangkan pembiayaan investasi mempunyai tren positif. Pada Januari 2011 sampai Desember 2015 rasio pembiayaan modal kerja cenderung menurun dari 53.5 persen hingga 44.4 persen, sedangkan rasio pembiayaan investasi cenderung meningkat dari 10.5 persen sampai 19.2 persen. Pembiayaan modal kerja dan investasi itu sendiri merupakan jenis pembiayaan produktif, seharusnya rasio pembiayaan modal kerja dan investasi keduanya perlu meningkat agar dapat memenuhi kebutuhan hidup sehari-hari dibandingkan pembiayaan yang sifatnya konsumtif.

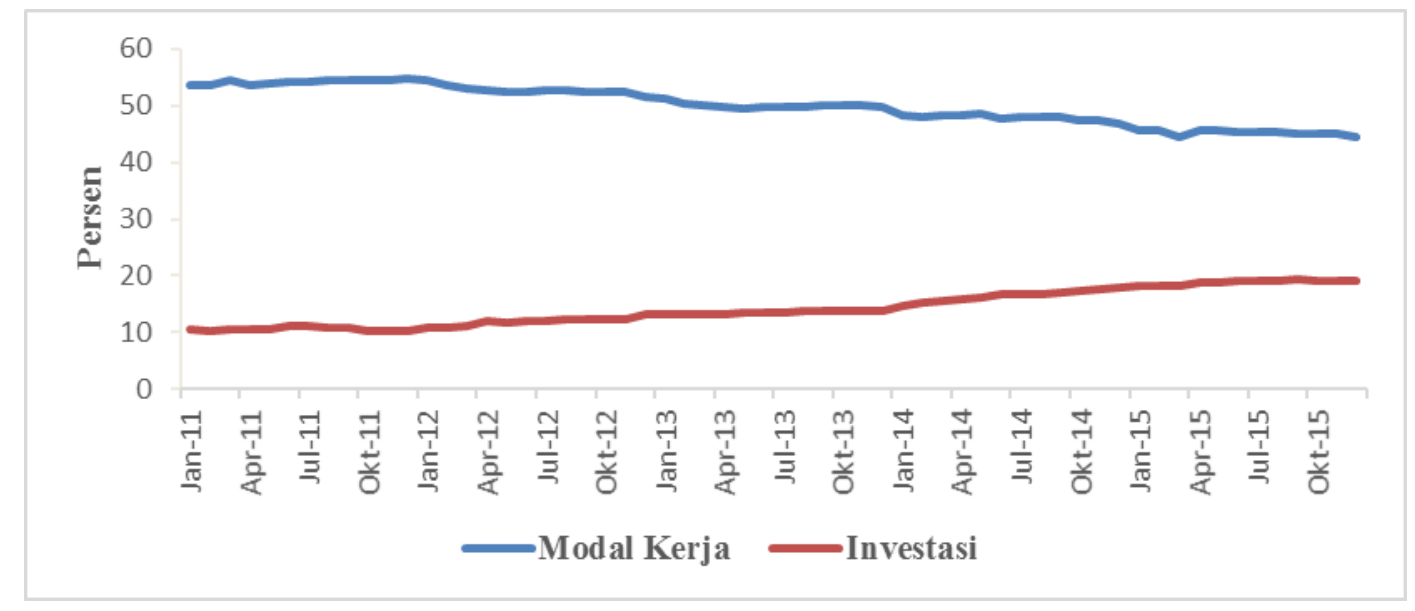

Sumber: Otoritas Jasa Keuangan (2015), diolah

Gambar 1 Rasio pembiayaan modal kerja dan investasi BPRS terhadap total pembiayaan 
Berdasarkan perumusan masalah yang telah diurai, maka tujuan penelitian ini adalah sebagai berikut :

1. Menganalisis perbandingan pengaruh kinerja BPRS dan kondisi makroekonomi terhadap penyaluran pembiayaan modal kerja dan investasi BPRS di Indonesia.

2. Menganalisis respon pembiayaan modal kerja dan investasi BPRS di Indonesia terhadap guncangan variabel kinerja BPRS dan kondisi makroekonomi.

3. Menganalisis kontribusi masing-masing variabel dalam menjelaskan keragaman tingkat pembiayaan modal kerja dan investasi BPRS di Indonesiia

Ruang lingkup penelitian ini dibatasi hanya pada pembiayaan dengan jenis penggunaan untuk modal kerja dan investasi. Ruang lingkup perbankan yang diteliti dibatasi hanya pada seluruh Bank Pembiayaan Rakyat Syariah (BPRS) di Indonesia. Penelitian ini menggunakan data time series bulanan dari Januari 2011 sampai dengan Desember 2015. Penelitian ini menganalisis pengaruh dan respon pembiayaan modal kerja dan investasi terhadap guncangan variabel kinerja BPRS yang terdiri atas Dana Pihak Ketiga (DPK), Capital Adequacy Ratio (CAR), Return On Assets (ROA), Non Performing Finance (NPF), Financing to Deposit Ratio (FDR), Biaya Operasional Pendapatan Operasional (BOPO), Equivalent Rate Pembiayaan (ERP), Equivalent Rate Dana Pihak Ketiga (ERDPK), serta variabel kondisi makroekonomi yang terdiri atas BI Rate (suku bunga acuan Bank Indonesia), inflasi dan Industrial Production Index (IPI). Selain itu, penelitian ini akan menjelaskan kontribusi masing-masing variabel terhadap pembiayaan modal kerja dan investasi BPRS di Indonesia.

\section{METODE}

\section{Jenis dan Sumber Data}

Jenis data yang digunakan dalam penelitian ini adalah data sekunder berupa data deret waktu (time series). Data deret waktu dengan frekuensi bulanan dari Januari 2011 sampai Desember 2015. Data penelitian bersumber dari berbagai publikasi yang tersedia di Bank Indonesia yaitu dari Statistik Perbankan Indonesia Bank Indonesia (SPI-BI), publikasi Otoritas Jasa Keuangan yaitu dari Statistik Perbankan Syariah Otoritas Jasa Keuangan (SPS-OJK), dan Badan Pusat Statistik (BPS).

\section{Metode Analisis dan Pengolahan Data}

Metode analisis dan pengolahan data yang digunakan dalam penelitian ini adalah metode deskriptif dan metode kuantitatif. Metode deskriptif dilakukan untuk menggambarkan data yang akan digunakan dan untuk memudahkan dalam penafsiran. Metode kuantitatif digunakan untuk menganalisis faktor-faktor yang secara signifikan memengaruhi pembiayaan jasa dunia usaha pada BPRS dengan menggunakan analisis deret waktu (time series).

Juanda dan Junaidi (2012) menyatakan bahwa sebagian besar model-model ekonometrika deret waktu adalah model struktural atau teoritis, yaitu model yang dibangun berdasarkan teori ekonomi yang ada. Estimasi model ini dapat memberikan informasi numerik maupun data untuk menguji teori yang ada. Namun, sering kali teori ekonomi belum mampu menentukan spesifikasi yang tepat untuk model dikarenakan fenomena ekonomi yang ada terlalu kompleks. Vector Autoregressive (VAR) dapat digunakan untuk mengatasi hal ini pada data deret waktu (time series) karena model VAR dibangun dengan pendekatan yang meminimalkan teori agar dapat menangkap fenomena yang ada.

Alat analisis yang digunakan dalam penelitian ini adalah metode Vector Autoregression (VAR) apabila data yang digunakan stasioner dan tidak ada kointegrasi, sedangkan apabila data yang digunakan stasioner dan ada kointegrasi maka digunakan metode Vector Error Correction Model (VECM). Oleh karena itu, sebelum melakukan analisis menggunakan metode VAR/VECM, 
diperlukan beberapa pengujian, di antaranya uji stasioneritas (unit root test), uji stabilitas VAR, uji lag optimum, dan uji kointegrasi. Selanjutnya, akan dilakukan VECM, Impuls Respon Function (IRF), dan Forecasting Error Variance Decomposition (FEVD). Kemudian proses analisis data dalam penelitian ini dilakukan dengan menggunakan bantuan software Microsoft Excel 2013 dan Eviews 6.

\section{Model Penelitian}

Terdapat dua model yang akan dianalisis dalam penelitian ini, yakni model pembiyaan modal kerja dan pembiayaan investasi. Kedua model ini merupakan model VECM. Berikut persamaan matematis dari kedua model yang akan dianalisis:

a. Model VECM pembiayaan modal kerja:

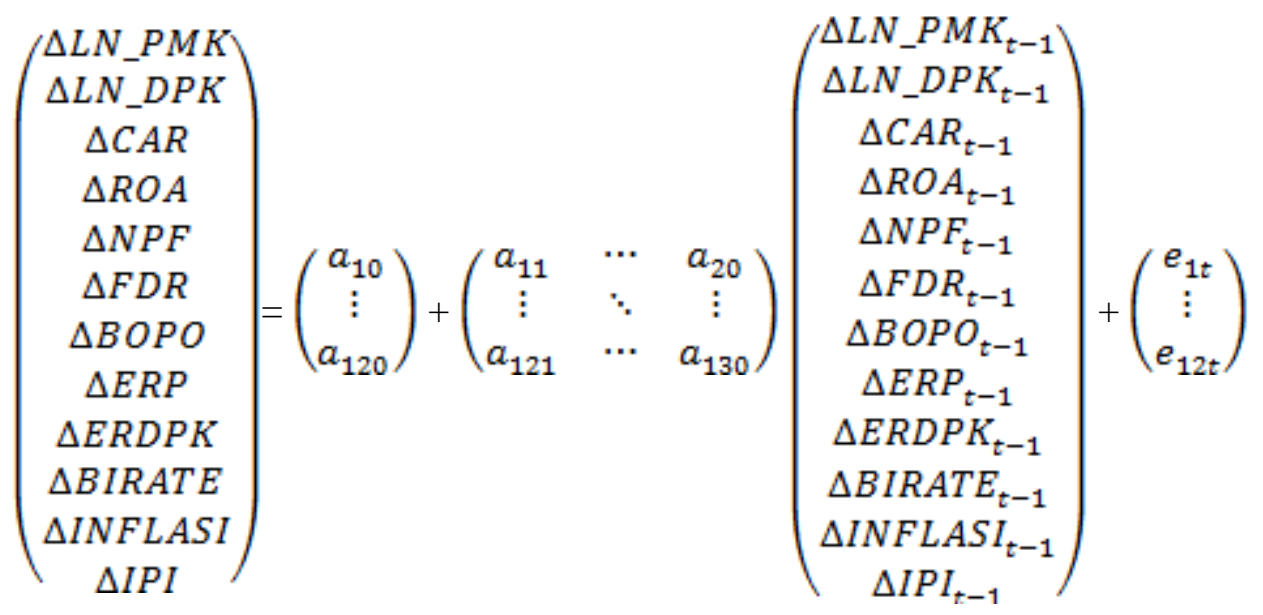

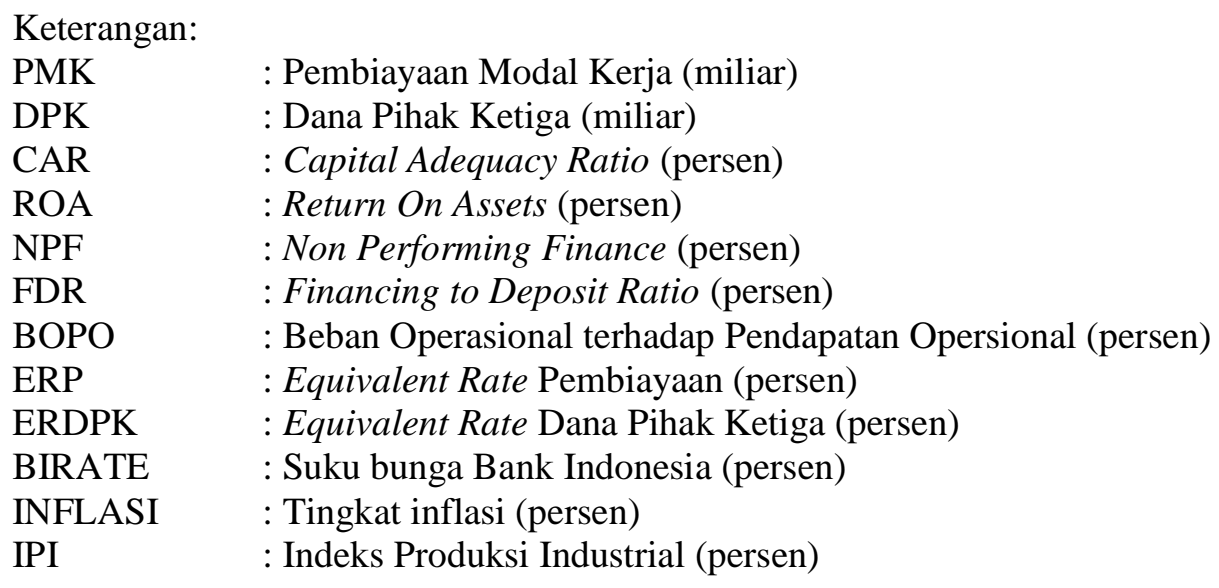


b. Model VECM pembiayaan investasi:

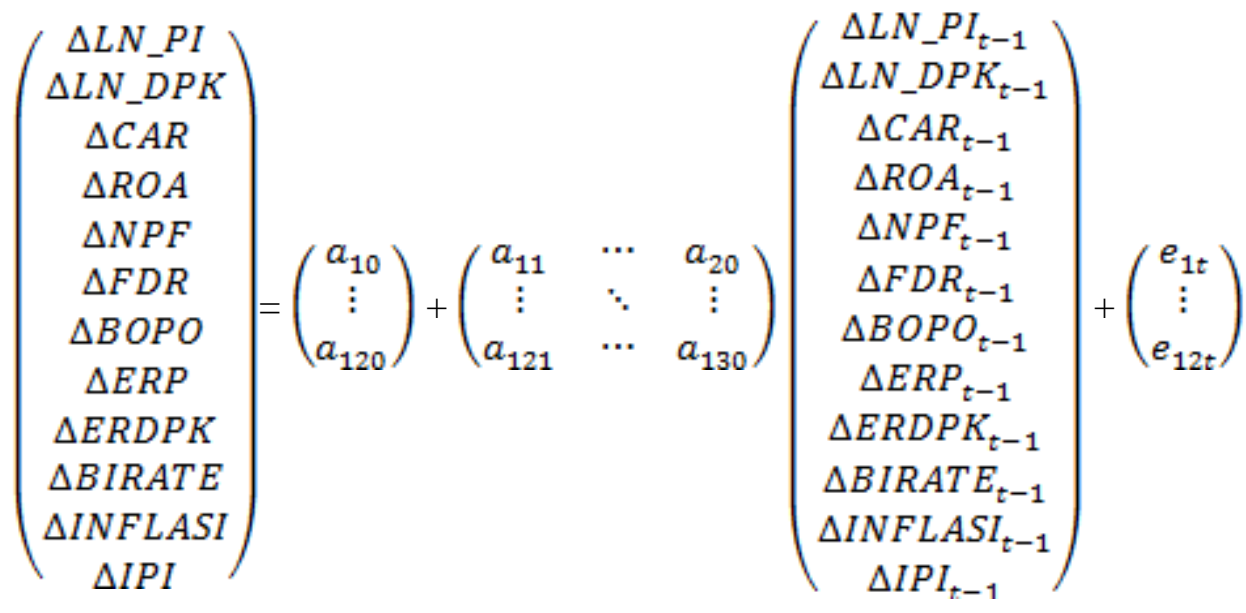

Keterangan:

$\begin{array}{ll}\text { PI } & \text { : Pembiayaan Investasi (miliar) } \\ \text { DPK } & \text { : Dana Pihak Ketiga (miliar) } \\ \text { CAR } & \text { : Capital Adequacy Ratio } \text { (persen) } \\ \text { ROA } & : \text { Return On Assets (persen) } \\ \text { NPF } & \text { : Non Performing Finance (persen) } \\ \text { FDR } & : \text { Financing to Deposit Ratio (persen) } \\ \text { BOPO } & : \text { Beban Operasional terhadap Pendapatan Opersional (persen) } \\ \text { ERP } & : \text { Equivalent Rate Pembiayaan (persen) } \\ \text { ERDPK } & : \text { Equivalent Rate Dana Pihak Ketiga (persen) } \\ \text { BIRATE } & : \text { Suku bunga Bank Indonesia (persen) } \\ \text { INFLASI } & : \text { Tingkat inflasi (persen) } \\ \text { IPI } & : \text { Indeks Produksi Industrial (persen) }\end{array}$

\section{HASIL DAN PEMBAHASAN}

\section{Hasil Uji Stasioneritas Data}

Uji stasioneritas merupakan hal yang penting saat melakukan estimasi model untuk data time series. Uji ini dilakukan agar tidak terjadi spurious regression yang menyebabkan hasil estimasi menjadi tidak tepat karena adanya unit root pada variabel yang digunakan. Uji stasioneritas yang biasa digunakan yaitu uji Augmented-Dickey-Fuller (ADF) dan Phillips Perron (PP) dengan nilai kritis sebesar 1 persen, 5 persen dan 10 persen. Uji stasioneritas pertama dilakukan pada tingkat level. Jika pada tingkat ini diketahui terdapat akar unit dalam data maka selanjutnya dilakukan uji stasioneritas pada first difference. Uji stasioneritas pada first difference dilakukan dengan menurunkan data pada first difference-nya. Akan tetapi jika masih terdapat akar unit pada first difference dapat dilakukan uji stasioneritas pada second difference. Akan tetapi dalam analisis pada second difference harus dilakukan dengan berhati-hati agar tidak kehilangan makna dari variabel yang dianalisis. Hasil uji stasioneritas pada penelitian ini tampak pada Tabel 3. 
Tabel 3 Hasil uji stasioneritas

\begin{tabular}{lcccc}
\hline \multirow{2}{*}{ Variabel } & \multicolumn{2}{c}{ Level } & \multicolumn{2}{c}{ First Difference } \\
\cline { 2 - 5 } & ADF-statistik & $\begin{array}{c}\text { Nilai Kritis } \\
\text { MacKinnon }\end{array}$ & ADF-statistik & $\begin{array}{c}\text { Nilai Kritis } \\
\text { MacKinnon }\end{array}$ \\
\hline LNPMK & $-3.979501^{*}$ & -2.911730 & $-5.486139^{*}$ & -2.912631 \\
LNPI & -1.731495 & -2.917650 & $-5.597174^{*}$ & -2.912631 \\
LNDPK & -2.249937 & -2.911730 & $-4.875976^{*}$ & -2.912631 \\
CAR & $-3.350143^{*}$ & -2.911730 & $-10.96439^{*}$ & -2.912631 \\
ROA & -1.712693 & -2.911730 & $-9.755607^{*}$ & -2.912631 \\
NPF & -1.752299 & -2.911730 & $-9.446688^{*}$ & -2.912631 \\
FDR & -1.992027 & -2.917650 & $-7.249002^{*}$ & -2.917650 \\
BOPO & 1.226411 & -2.911730 & $-9.834881^{*}$ & -2.912631 \\
ERP & -2.215892 & -2.911730 & $-8.221320^{*}$ & -2.912631 \\
ERDPK & $-6.018958^{*}$ & -2.911730 & $-9.912448^{*}$ & -2.913549 \\
BIRATE & -1.130581 & -2.912631 & $-4.691225^{*}$ & -2.912631 \\
INFLASI & -2.343917 & -2.912631 & $-5.019929^{*}$ & -2.912631 \\
IPI & -0.531061 & -2.913549 & $-9.400379^{*}$ & -2.913549 \\
\hline
\end{tabular}

Sumber: Data penelitian (diolah)

Hasil pengujian unit root pada tingkat level menunjukkan bahwa terdapat tiga variabel yang stasioner, yaitu LNPMK, CAR, dan ERDPK pada taraf nyata lima persen. Akan tetapi, pada tingkat first difference seluruh variabel baik kinerja BPRS maupun kondisi makroekonomi stasioner pada taraf nyata lima persen. Hal ini dapat dilihat dari nilai ADF-statistik yang lebih kecil dari pada nilai koefisien MacKinnon. Penggunaan variabel yang tidak stasioner dapat menyebabkan regresi yang semu (spurious regression). Regresi semu akan menghasilkan hubungan dua variabel atau lebih yang signifikan secara statistik, namun hasil penelitiannya akan berbeda dengan fenomena ekonomi yang terjadi sebenarnya. Oleh karena itu, dilakukan uji lanjutan pada tingkat first difference untuk melihat ada atau tidaknya akar unit pada tingkat tersebut. Informasi jangka panjang akan hilang pada saat menggunakan data pada tingkat first difference, sehingga metode VAR akan dikombinasi dengan model koreksi kesalahan (error correction model) menjadi VECM untuk menganalisis informasi jangka panjang dengan memanfaatkan data pada tingkat level.

\section{Hasil Uji Stabilitas VAR}

Pengujian berikutnya adalah melakukan uji stabilitas model VAR. Uji ini diperlukan untuk memeroleh hasil Impulse Response Function (IRF) dan Forecast Error Variance Decomposition (FEVD) yang valid. Nilai modulus model pembiayaan modal kerja pada penelitian ini berada pada kisaran nilai 0.028-0.995, sedangkan nilai modulus model pembiayaan investasi berada pada kisaran nilai 0.127-0.989. Berdasarkan hasil pengujian stabilitas model VAR tersebut, dapat disimpulkan bahwa sistem VAR adalah stabil dikarenakan seluruh akarnya berada dalam unit circle atau memiliki nilai modulus kurang dari satu maka model VAR tersebut dianggap stabil sehingga Impulse Response Function (IRF) dan Forecast Error Variance Decomposition (FEVD) yang dihasilkan dianggap valid (Firdaus, 2011).

\section{Hasil Uji Lag Optimum}

Uji lag optimal merupakan langkah penting yang harus dilakukan dalam menggunakan model VAR. Lag optimal dimaksudkan untuk menunjukkan berapa lama reaksi suatu variabel terhadap variabel lainnya serta untuk menghilangkan masalah autokorelasi dalam sebuah sistem VECM. Uji ini tersedia dalam beberapa jenis informasi, diantaranya adalah Akaike Information Criterion 
(AIC), Schwarz Criterion (SC), dan Hannan-Quinn Criterion (HQ). Berikut adalah hasil uji lag optimal pembiayaan modal kerja.

Tabel 4 Hasil uji lag optimal pembiayaan modal kerja

\begin{tabular}{ccccccc}
\hline Lag & LogL & LR & FPE & AIC & SC & HQ \\
\hline 0 & -605.1378 & NA & $4.12 \mathrm{e}-06$ & 21.65396 & 22.08408 & 21.82112 \\
1 & -24.84446 & $895.8915^{*}$ & $1.02 \mathrm{e}-12^{*}$ & 6.345420 & $11.93693^{*}$ & $8.518470^{*}$ \\
2 & 113.3245 & 155.1370 & $2.44 \mathrm{e}-12$ & 6.550019 & 17.30292 & 10.72896 \\
3 & 332.4146 & 153.7475 & $1.62 \mathrm{e}-12$ & $3.915276^{*}$ & 19.82957 & 10.10011 \\
\hline
\end{tabular}

Sumber: Data penelitian (diolah)

Hasil uji lag optimal pembiayaan modal kerja menunjukkan bahwa kriteria Schwarz Criterion (SC), lag optimum yang dihasilkan berada pada lag ke-1, sedangkan berdasarkan kriteria Akaike Information Criterion (AIC) berada pada lag ke-3 dan Hannan-Quinn Criterion (HQ) lag optimal berada pada lag ke-1. Selanjutnya merupakan hasil uji lag optimal pembiayaan investasi.

Tabel 5 Hasil uji lag optimal pembiayaan investasi

\begin{tabular}{rcccccc}
\hline Lag & LogL & LR & FPE & AIC & SC & HQ \\
\hline 0 & -652.3796 & NA & $2.16 \mathrm{e}-05$ & 23.31156 & 23.74168 & 23.47872 \\
1 & -53.30875 & $924.8813^{*}$ & $2.77 \mathrm{e}-12^{*}$ & 7.344167 & $12.93568^{*}$ & $9.517218^{*}$ \\
2 & 82.08357 & 152.0195 & $7.30 \mathrm{e}-12$ & 7.646190 & 18.39909 & 11.82513 \\
3 & 313.6512 & 162.5036 & $3.13 \mathrm{e}-12$ & $4.573642^{*}$ & 20.48794 & 10.75848 \\
\hline
\end{tabular}

Sumber: Data penelitian (diolah)

Hasil uji lag optimal pembiayaan modal kerja menunjukkan bahwa kriteria Schwarz Criterion (SC), lag optimum yang dihasilkan berada pada lag ke-1, sedangkan berdasarkan kriteria Akaike Information Criterion (AIC) berada pada lag ke-3 dan Hannan-Quinn Criterion (HQ) lag optimal berada pada lag ke-1. Hasil uji lag optimal pada kriteria Schwarz Criterion (SC), Akaike Information Criterion (AIC), dan Hannan-Quinn Criterion (HQ) pada pembiayaan modal kerja dan investasi BPRS di Indonesia menunjukkan hasil lag optimal yang sama. Pada penelitian ini, kriteria lag optimum yang digunakan adalah Schwarz Criterion (SC) yang berada pada lag ke-1.

\section{Hasil Uji Kointegrasi}

Uji kointegrasi dimaksudkan untuk menentukan ada atau tidaknya variabel-variabel yang tidak stasioner pada tingkat level yang terkointegrasi. Pengujian kointegrasi pada penelitian ini menggunakan metode Johansen Trace Statistic test. Informasi jangka panjang diperoleh dengan menentukan rank kointegrasi terlebih dahulu. Hal ini dimaksudkan untuk mengetahui jumlah sistem persamaan yang dapat menerangkan keseluruhan sistem yang ada. Kriteria pengujian kointegrasi pada penelitian ini didasarkan pada nilai trace statistic. Jika nilai trace statistic lebih besar daripada nilai kritis lima persen, maka hipotesis alternatif yang menyatakan jumlah kointegrasi diterima, sehingga dapat diketahui jumlah persamaan yang terkointegrasi dalam sistem. Berikut hasil uji kointegrasi pembiayaan modal kerja. 
Tabel 6 Hasil uji kointegrasi pembiayaan modal kerja

\begin{tabular}{lcccc}
\hline $\begin{array}{c}\text { Hypothesized No } \\
\text { of CE }(s)\end{array}$ & Eigenvalue & $\begin{array}{c}\text { Trace } \\
\text { Statistic }\end{array}$ & $\begin{array}{c}\text { 0.05 Critical } \\
\text { Value }\end{array}$ & Prob ** \\
\hline None & $0.830267^{*}$ & 478.9958 & 348.9764 & 0.0000 \\
At most 1 & $0.751703^{*}$ & 376.1311 & 298.1594 & 0.0000 \\
At most 2 & $0.628070^{*}$ & 295.3296 & 251.2650 & 0.0001 \\
At most 3 & $0.580969^{*}$ & 237.9647 & 208.4374 & 0.0008 \\
At most 4 & $0.549112^{*}$ & 187.5157 & 169.5991 & 0.0039 \\
At most 5 & $0.447386^{*}$ & 141.3166 & 134.6780 & 0.0192 \\
At most 6 & $0.404843^{*}$ & 106.9170 & 103.8473 & 0.0308 \\
At most 7 & 0.339694 & 76.81911 & 76.97277 & 0.0514 \\
At most 8 & 0.306341 & 52.74612 & 54.07904 & 0.0655 \\
At most 9 & 0.202883 & 31.53117 & 35.19275 & 0.1178 \\
At most 10 & 0.176084 & 18.37945 & 20.26184 & 0.0889 \\
At most 11 & 0.115914 & 7.145629 & 9.164546 & 0.1189 \\
\hline
\end{tabular}

Sumber: Data penelitian (diolah)

Dapat dilihat bahwa hasil uji Johansen pada pembiayaan modal kerja, terdapat tujuh hubungan kointegrasi yaitu saat nilai trace statistic lebih besar daripada nilai kritisnya. Hasil ini menunjukkan bahwa terdapat hubungan jangka panjang antar variabel dalam model, sehingga model VAR dapat dikombinasikan dengan ECM menjadi VECM. Hasil uji kointegrasi pembiayaan investasi dapat dilihat pada Tabel 7.

Dapat dilihat bahwa hasil uji Johansen pada pembiayaan investasi, terdapat enam hubungan kointegrasi yaitu saat nilai trace statistic lebih besar daripada nilai kritisnya. Hasil ini menunjukkan bahwa juga terdapat hubungan jangka panjang antar variabel dalam model, sehingga model VAR dapat dikombinasikan dengan ECM menjadi VECM.

Tabel 7 Hasil uji kointegrasi pembiayaan investasi

\begin{tabular}{lcccc}
\hline $\begin{array}{c}\text { Hypothesized No } \\
\text { of CE }(s)\end{array}$ & Eigenvalue & $\begin{array}{c}\text { Trace } \\
\text { Statistic }\end{array}$ & $\begin{array}{c}\text { 0.05 Critical } \\
\text { Value }\end{array}$ & Prob ** \\
\hline None & $0.784176^{*}$ & 484.2444 & 358.7184 & 0.0000 \\
At most 1 & $0.760393^{*}$ & 395.3136 & 306.8944 & 0.0000 \\
At most 2 & $0.723722^{*}$ & 312.4456 & 259.0294 & 0.0000 \\
At most 3 & $0.612884^{*}$ & 237.8375 & 215.1232 & 0.0025 \\
At most 4 & $0.556705^{*}$ & 182.7937 & 175.1715 & 0.0187 \\
At most 5 & 0.472099 & 135.6096 & 139.2753 & 0.0803 \\
At most 6 & 0.365181 & 98.55649 & 107.3466 & 0.1637 \\
At most 7 & 0.322506 & 72.20040 & 79.34145 & 0.1528 \\
At most 8 & 0.258875 & 49.61783 & 55.24578 & 0.1427 \\
At most 9 & 0.212834 & 32.24182 & 35.01090 & 0.0961 \\
At most 10 & 0.179973 & 18.36147 & 18.39771 & 0.0506 \\
At most 11 & $0.111445^{*}$ & 6.853192 & 3.841466 & 0.0088 \\
\hline
\end{tabular}

Sumber: Data penelitian (diolah)

\section{Hasil Estimasi VECM}

Hasil estimasi VECM menunjukkan hubungan jangka panjang dari pembiayaan modal kerja dan pembiayaan investasi, kinerja BPRS yaitu capital adequacy ratio (CAR), return on assets (ROA), non performing financing (NPF), financing to deposit ratio (FDR), biaya operasional terhadap pendapatan operasional (BOPO), dan tingkat bagi hasil baik bagi pihak bank (ERP) maupun 
nasabah (ERDPK), dan kondisi makroekonomi yaitu bi rate, inflasi dan indeks produksi indusstri (IPI). Pada estimasi ini, pembiayaan modal kerja dan pembiayaan investasi sebagai variabel dependen sedangkan variabel-variabel kinerja BPRS dan kondisi makroekonomi masing-masing pada lag 1 sebagai variabel independennya. Berikut hasil estimasi model VECM jangka panjang baik pembiayaan modal kerja maupun pembiayaan investasi.

Hasil estimasi VECM yang memperlihatkan tentang pengaruh variabel-variabel kinerja BPRS dan kondisi makroekonomi pada jangka panjang terhadap pembiayaan modal kerja dan pembiayaan investasi BPRS di Indonesia akan dibahas dan dibandingkan pada setiap variabelnya baik pengaruhnya positif maupun negatif, sehingga dapat memberikan saran dan rekomendasi dalam penentuan pembiayaan modal kerja dan investasi BPRS di Indonesia.

Variabel dana pihak ketiga pada jangka panjang berpengaruh positif secara signifikan baik terhadap pembiayaan modal kerja maupun pembiayaan investasi BPRS di Indonesia. Artinya semakin besar jumlah dana pihak ketiga BPRS maka akan meningkatkan jumlah pembiayaan modal kerja dan investasi BPRS di Indonesia. BPRS sebagai lembaga intermediasi bertugas menghimpun dana dalam bentuk simpanan dan menyalurkannya dalam bentuk pembiayaan. Danadana yang dihimpun dari masyarakat ini merupakan salah satu sumber dana terbesar BPRS, sehingga peningkatan jumlah dana pihak ketiga ini akan meningkatkan sumber pendanaan bagi BPRS dan dapat meningkat peranan BPRS di Indonesia dalam menyalurkan pembiayaan (Kusumawati,2016). Termasuk didalamnya pembiayaan modal kerja dan investasi yang jumlah nominalnya setiap periode terus bertambah meskipun rasio pembiayaan modal kerja setiap periode cenderung mengalami penurunan.

Variabel capital adequacy ratio pada jangka panjang tidak berpengaruh signifikan terhadap pembiayaan modal kerja, akan tetapi berpengaruh positif secara signifikan terhadap pembiayaan investasi BPRS di Indonesia. Artinya semakin besar capital adequacy ratio BPRS maka akan meningkat jumlah pembiayaan investasi akan tetapi tidak berpengaruh terhadap pembiayaan modal kerja BPRS di Indonesia. Capital adequacy ratio merupakan rasio permodalan yang menunjukkan kemampuan BPRS dalam menyediakan dana untuk keperluan pengembangan usaha dan menampung risiko kerugian dana yang diakibatkan oleh kegiatan operasional BPRS. Menurut Carlson et al. (2013) bahwa jumlah modal yang dimiliki oleh bank memengaruhi besarnya kredit atau pembiayaan yang mereka salurkan, sehingga peningkatan rasio permodalan BPRS juga akan meningkatkan sumber daya finansial yang dapat digunakan untuk mengantisipasi kerugian yang diakibatkan oleh penyaluran pembiayaan investasi.

Variabel return on assets pada jangka panjang berpengaruh negatif secara signifikan terhadap pembiayaan modal kerja, sedangkan berpengaruh positif secara signifikan terhadap pembiayaan investasi BPRS di Indonesia. Artinya semakin besar return on assets BPRS maka akan meningkat jumlah pembiayaan investasi BPRS di Indonesia, namun menurun pada jumlah pembiayaan modal kerja BPRS di Indonesia. Return on assets merupakan kinerja BPRS yang mempresentasikan profitabilitas BPRS itu sendiri. Peningkatan profitabilitas atau keuntungan yang diperoleh BPRS akan menurunkan jumlah pembiayaan modal kerja namun meningkatkan pembiayaan investasi. Artinya pihak BPRS lebih memilih menyalurkan pembiayaan untuk investasi yang dinilai lebih menguntungkan BPRS itu sendiri dibandingkan untuk modal kerja (Sari, 2013). Hal ini terbukti bahwa persentase pembiayaan investasi setiap periode cenderung terus meningkat dibandingkan pembiayaan modal kerja yang persentasenya cenderung menurun pada setiap periode meskipun persentasenya lebih besar.

Variabel non performing financing pada jangka panjang berpengaruh negatif secara signifikan baik terhadap pembiayaan modal kerja maupun pembiayaan investasi BPRS di Indonesia. Artinya semakin besar non performing financing BPRS maka akan menurunkan jumlah pembiayaan modal 
kerja dan investasi BPRS di Indonesia. Hubungan negatif antara NPF dan pembiayaan modal kerja dan investasi terjadi karena semakin tingginya pembiayaan bermasalah pada modal kerja maupun investasi menyebabkan dana BPRS menjadi tidak dapat berputar dari satu nasabah ke nasabah lainnya (Jaya et al., 2015). Hal ini juga mengakibatkan turunnya minat BPRS untuk menyalurkan pembiayaan modal kerja dan investasi.

Tabel 8 Hasil estimasi VECM jangka panjang

\begin{tabular}{lcr}
\hline & Jangka Panjang Pembiayaan Modal Kerja 2015 \\
\hline Variabel & Koefisien & t-statistik \\
\hline LNDPK & $0.932514^{*}$ & 30.3997 \\
CAR & 0.015593 & 0.1157 \\
ROA & $-0.027808^{*}$ & -2.2918 \\
NPF & $-0.035676^{*}$ & -8.4024 \\
FDR & $0.009087^{*}$ & 12.991 \\
BOPO & $-0.004072^{*}$ & -3.7955 \\
ERP & -0.001580 & -1.0406 \\
ERDPK & $0.021295^{*}$ & 5.2633 \\
BIRATE & $-0.019669^{*}$ & -3.6095 \\
INFLASI & $0.008294^{*}$ & 3.9670 \\
IPI & $0.001150^{*}$ & 2.1527 \\
\hline
\end{tabular}

\begin{tabular}{lcr}
\hline & Jangka Panjang Pembiayaan Investasi 2015 \\
\hline Variabel & Koefisien & t-statistik \\
\hline LNDPK & $0.957930^{*}$ & 5.59274 \\
CAR & $0.020031^{*}$ & 3.30846 \\
ROA & $0.089077^{*}$ & 2.46805 \\
NPF & $-0.083184^{*}$ & -5.11334 \\
FDR & $0.014378^{*}$ & 7.05774 \\
BOPO & $-0.008911^{*}$ & -2.65139 \\
ERP & $-0.016295^{*}$ & -3.76993 \\
ERDPK & $-0.071746^{*}$ & -6.08709 \\
BIRATE & $0.087320^{*}$ & 5.41932 \\
INFLASI & $-0.040283^{*}$ & -6.46282 \\
IPI & $0.012099^{*}$ & 7.58287 \\
\hline
\end{tabular}

Sumber: Data penelitian (diolah)

*signifikan pada taraf nyata $5 \%$

Variabel financing to deposit ratio pada jangka panjang berpengaruh positif secara signifikan baik terhadap pembiayaan modal kerja maupun pembiayaan investasi BPRS di Indonesia. Artinya semakin besar financing to deposit ratio BPRS maka akan meningkatkan jumlah pembiayaan modal kerja dan investasi BPRS di Indonesia. Financing to deposit ratio merupakan perbandingan jumlah pembiayaan yang dilakukan baik untuk modal kerja maupun investasi terhadap total dana pihak ketiga. Hasil ini sejalan dengan penelitian Kusumawati (2013) dimana ketika FDR modal kerja dan investasi meningkat maka akan meningkatkan total pembiayaan untuk modal kerja dan investasi.

Variabel biaya operasional terhadap pendapatan operasional pada jangka panjang berpengaruh negatif secara signifikan baik terhadap pembiayaan modal kerja maupun pembiayaan investasi BPRS di Indonesia. Artinya semakin besar biaya operasional terhadap pendapatan operasional BPRS maka akan menurunkan jumlah pembiayaan modal kerja dan investasi BPRS di Indonesia. BOPO merupakan indikator efisiensi dari kegiatan operasional BPRS (Dendiwijaya, 2005). Hasil 
dari penelitian ini adalah BOPO semakin tinggi akan menurunkan besaran penyaluran pembiayaan modal kerja dan investasi. Artinya semakin tidak efisiennya kinerja BPRS, pembiayaan modal kerja dan investasi akan semakin kecil. Hal ini terjadi karena saat beban operasional yang ditanggung oleh BPRS lebih besar dibandingkan dengan pendapatan yang diperoleh, maka BPRS akan mengurangi porsi pembiayaan untuk menekan beban operasionalnya.

Variabel equivalent rate pembiayaan pada jangka panjang tidak berpengaruh signifikan terhadap pembiayaan modal kerja, akan tetapi berpengaruh negatif secara signifikan terhadap pembiayaan investasi BPRS di Indonesia. Artinya semakin besar equivalent rate pembiayaan BPRS maka akan meningkat jumlah pembiayaan investasi akan tetapi tidak berpengaruh terhadap pembiayaan modal kerja BPRS di Indonesia. Keadaan ERP berpengaruh negatif terhadap pembiayaan investasi disebabkan karena ERP bagi nasabah merupakan bagian dari cost of capital sehingga ketika ERP meningkat maka akan meningkatkan biaya produksi dan menurunnya keuntungan yang nasabah terima (Jaya, et al., 2015). Hal ini menyebabkan nasabah akan beralih untuk mencari pembiayaan kepada pihak lain yang menawarkan pembiayaan dengan tingkat bagi hasil pembiayaan yang lebih rendah. Hal ini disebabkan nasabah sudah tidak tertarik lagi terhadap pembiayaan yang ditawarkan BPRS.

Variabel equivalent rate dana pihak ketiga pada jangka panjang berpengaruh positif secara signifikan terhadap pembiayaan modal kerja, sedangkan berpengaruh negatif secara signifikan terhadap pembiayaan investasi BPRS di Indonesia. Artinya semakin besar equivalent rate dana pihak ketiga BPRS maka akan meningkat jumlah pembiayaan modal kerja BPRS di Indonesia, sedangkan menurun pada jumlah pembiayaan investasi BPRS di Indonesia. Hubungan negatif antara ERDPK dan pembiayaan investasi mengindikasikan bahwa pendapatan yang diterima nasabah lebih kecil dari pada pendapatan yang diterima oleh pihak BPRS dan sebagian dari hasil pendapatan BPRS mengindikasikan untuk meningkatkan volume pembiayaan investasi, sedangkan hubungan positif antara ERDPK dan pembiayaan modal kerja mengindikasikan BPRS untuk meningkatkan pendapatannya demi memenuhi kewajibannya kepada nasabah. Salah satunya melalui peningkatan jumlah pembiayaan modal kerja, selain pembiayaan untuk investasi. Hasil ini sesuai dengan penelitian yang dilakukan oleh Beik dan Aprianti (2013).

Variabel suku bunga Bank Indonesia pada jangka panjang berpengaruh negatif secara signifikan terhadap pembiayaan modal kerja, namun berpengaruh positif secara signifikan terhadap pembiayaan investasi BPRS di Indonesia. Artinya semakin besar suku bunga Bank Indonesia maka akan menurunkan jumlah pembiayaan modal kerja BPRS di Indonesia, disisi lain meningkatkan jumlah pembiayaan investasi BPRS di Indonesia. Suku bunga Bank Indonesia merupakan suku bunga acuan untuk bank konvensional karena belum adanya regulasi acuan bank syariah untuk tingkat bagi hasil, sehingga ketika BI rate naik, maka akan meningkatkan suku bunga kredit. Keadaan ini akan diikuti oleh bank konvensional untuk mengambil sebagian pangsa pasar dari bank syariah, akibatnya hal ini dapat menurunkan volume pembiayaan modal kerja BPRS di Indonesia (Jaya et al., 2015). Keadaan meningkatnya suku bunga kredit akan diikuti dengan meningkatnya tingkat bagi hasil pembiayaan agar perbankan syariah dapat bersaing dengan perbankan konvensional. Pembiayaan investasi merupakan pembiayaan dengan jangka waktu panjang, sehingga nasabah lebih memilih perbankan syariah yang menggunakan tingkat bagi hasil pembiayaan dan sudah ditentukan pada awal kesepakatan pembiayaan sehingga sifatnya tetap (fixed), tidak mengambang (float) seperti suku bunga kredit. Peningkatan tingkat bagi hasil pembiayaan, akan meningkatkan volume pembiayaan pada investasi. Hasil penelitian ini sesuai dengan penelitian Kusumawati (2013).

Variabel inflasi pada jangka panjang berpengaruh positif secara signifikan terhadap pembiayaan modal kerja, sedangkan berpengaruh negatif secara signifikan terhadap pembiayaan investasi BPRS di Indonesia. Artinya semakin besar inflasi maka akan meningkat jumlah pembiayaan 
modal kerja BPRS di Indonesia, sedangkan menurun pada jumlah pembiayaan investasi BPRS di Indonesia. Hubungan negatif antara inflasi dan pembiayaan investasi sesuai dengan teori dikarenakan ketika tingkat inflasi meningkat maka harga barang akan meningkat yang mengakibatkan nilai input pada produsen membengkak diperparah oleh turunnya daya beli masyarakat sehingga kemampuan nasabah untuk melakukan kewajiban dalam pembiayaan akan berkurang. BPRS akan membatasi jumlah uang yang beredar antara lain dengan cara membatasi pemberian kredit dan pembiayaan (Suryadi, et al., 2014). Hubungan positif inflasi dan pembiayaan modal kerja dikarenakan pada saat inflasi, harga barang akan mengalami kenaikan secara bersamaan yang berarti terjadi kenaikan total penerimaan. Peningkatan pada total penerimaan mendorong naiknya keuntungan, sehingga lebih memudahkan nasabah yang melakukan pembiayaan modal kerja mengembalikan pinjamannya kepada BPRS. Hal ini membuat BPRS meningkatkan pembiayaan kepada nasabah karena rate of return pembiayaan memiliki resiko yang rendah.

Variabel indeks produksi industri pada jangka panjang berpengaruh posititf secara signifikan baik terhadap pembiayaan modal kerja maupun pembiayaan investasi BPRS di Indonesia. Artinya semakin besar indeks produksi industri maka akan meningkatkan jumlah pembiayaan modal kerja dan investasi BPRS di Indonesia. Variabel IPI memiliki hubungan positif terhadap pembiayaan modal kerja dan investasi BPRS di Indonesia dikarenakan ketika perekonomian dalam kondisi yang baik maka akan mendukung penyelenggaraan aktifitas perbankan, termasuk penyaluran pembiayaan modal kerja dan investasi pada BPRS. Hal ini menunjukkan bahwa ekspansi pada pembiayaan modal kerja dan investasi BPRS di Indonesia dapat meningkatkan pendapatan nasional yang diproksimasi melalui IPI. Hal ini sesuai dengan prinsip perbankan syariah yang mengutamakan penyaluran dana pada sektor riil dalam rangka meningkatkan pendapatan nasional (Kusumawati, 2013).

\section{Hasil Analisis Impulse Response Function (IRF)}

Penelitian ini menggunakan menggunakan jangka waktu selama seratus bulan pada pembiayaan modal kerja dan dua puluh bulan pada pembiayaan investasi yang dilakukan oleh BPRS di Indonesia agar mengetahui kestabilan respon terhadap guncangan yang terjadi. Berikut ini adalah hasil simulasi IRF untuk pengaruh guncangan kinerja BPRS dan kondisi makroekonomi terhadap pembiayaan modal kerja dan investasi BPRS di Indonesia.

Guncangan dari dana pihak ketiga sebesar satu standar deviasi pada bulan pertama belum direspon baik terhadap pembiayaan modal kerja maupun pembiayaan investasi BPRS di Indonesia (Gambar 2). Pada bulan selanjutnya pembiayaan modal kerja dan investasi terus merespon positif guncangan yang terjadi oleh dana pihak ketiga. Pembiayaan modal kerja mulai stabil pada bulan ke-82 dengan nilai sebesar 0.093517 persen, sedangkan pembiayaan investasi mulai stabil pada bulan ke-10 dengan nilai sebesar 0.009272 persen. 

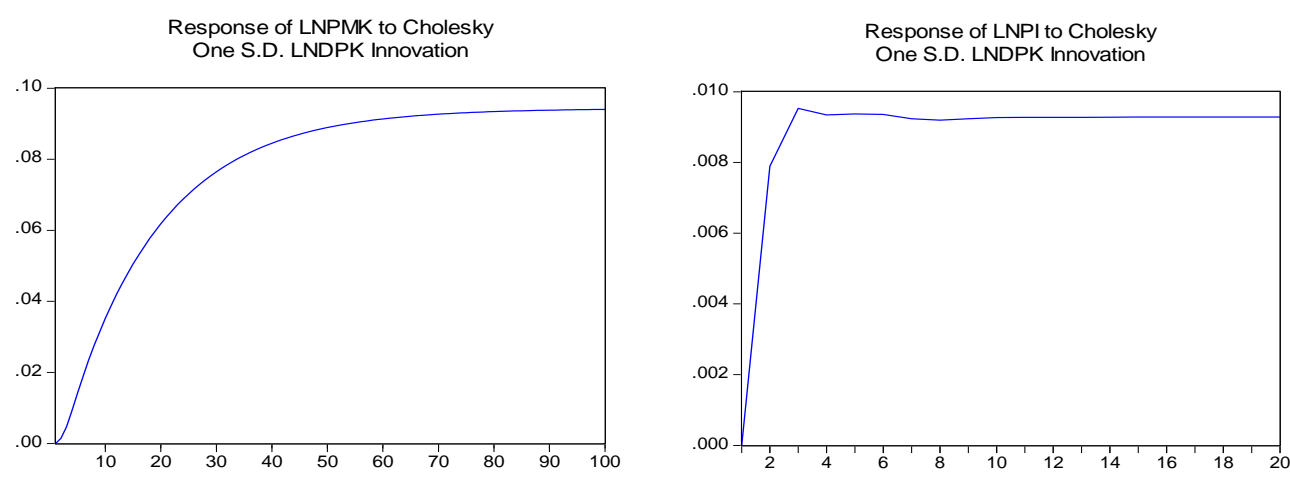

Gambar 2 Respon terhadap guncangan dana pihak ketiga

Guncangan dari capital adequacy ratio tampak belum direspon pada bulan pertama sebesar satu standar deviasi baik terhadap pembiayaan modal kerja maupun pembiayaan investasi BPRS di Indonesia (Gambar 3). Bulan selanjutnya guncangan capital adequacy ratio baru mulai direspon dengan respon yang negatif oleh pembiayaan modal kerja dan investasi tersebut. Pembiayaan modal kerja mulai stabil pada bulan ke-60 dengan nilai sebesar 0.008466 persen dan pembiayaan investasi mulai stabil pada bulan ke-12 dengan nilai sebesar 0.009204 persen.
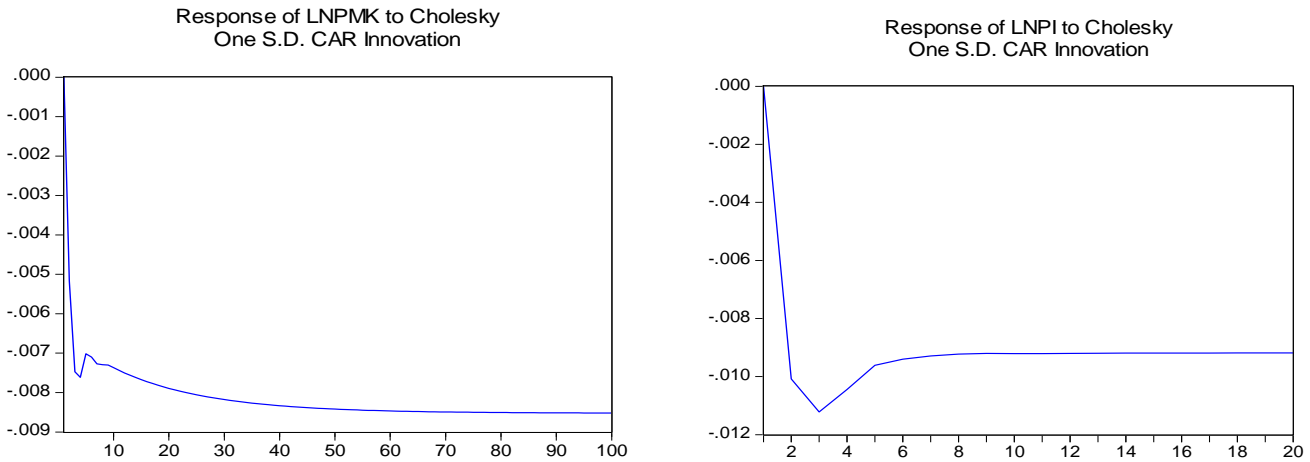

Gambar 3 Respon terhadap guncangan capital adequacy ratio
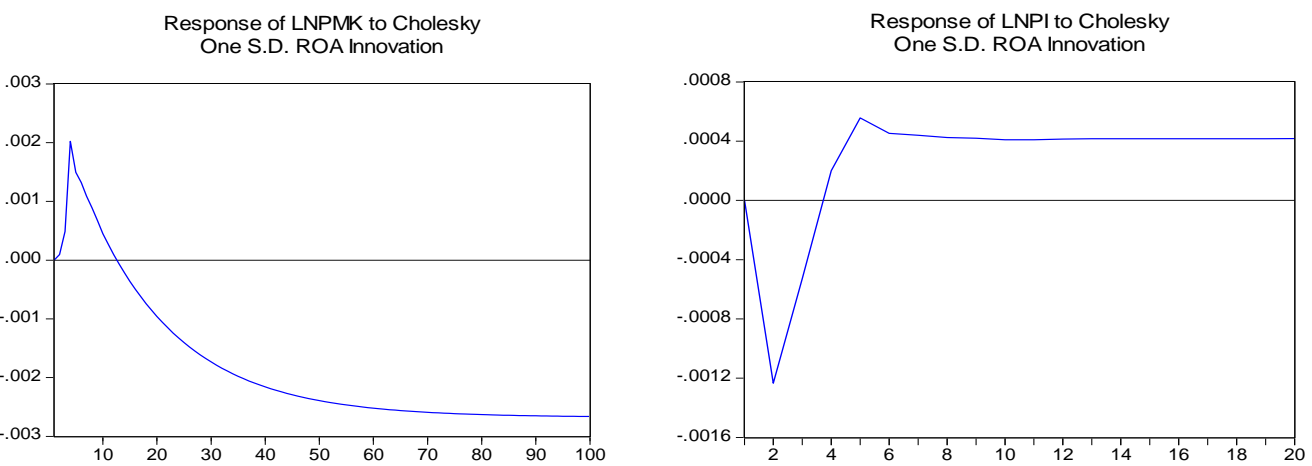

Gambar 4 Respon terhadap guncangan return on assets 

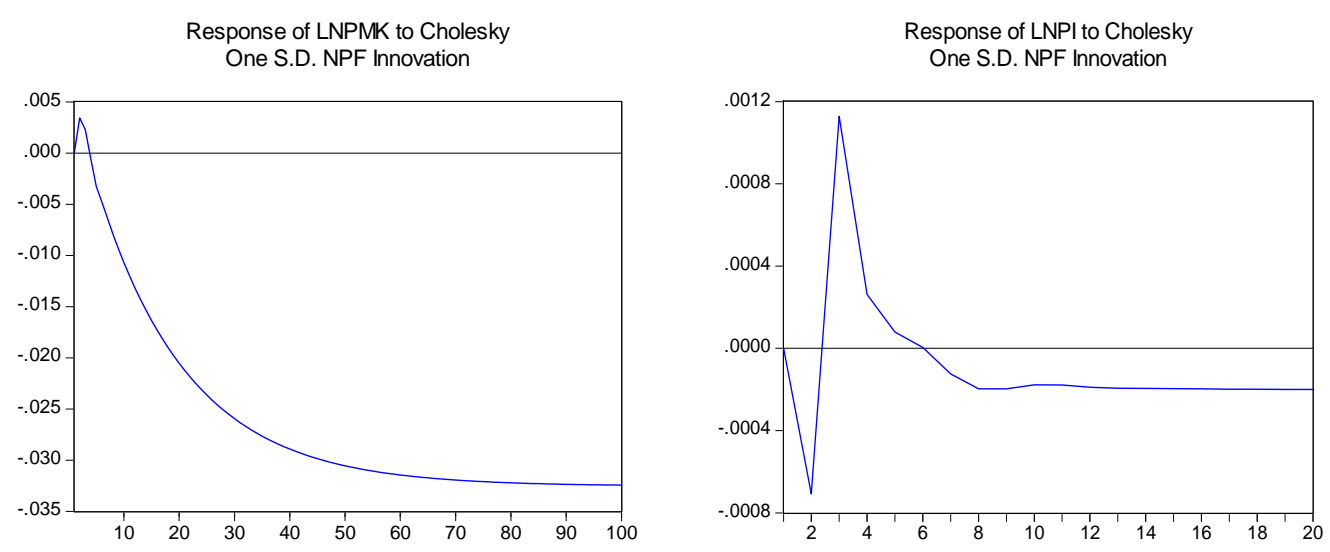

Gambar 5 Respon terhadap guncangan non performing financing

Guncangan dari non performing financing mulai direspon dengan respon yang berbeda pada bulan kedua sebesar satu standar deviasi terhadap pembiayaan modal kerja dan pembiayaan investasi BPRS di Indonesia (Gambar 5). Bulan ke-2 dan ke-3 ini, untuk pembiayaan modal kerja di respon positif akan tetapi bulan-bulan berikut direspon negatif hingga stabil pada bulan ke-90 dengan nilai mencapai 0.032364 persen. Pada pembiayaan investasi mengalami fluktuasi, saat bulan ke-2 direspon negatif baru mulai direspon positif pada bulan berikutnya hingga pada bulan ke-6 kemudian kembali direspon negatif hingga stabil pada bulan ke-13 dengan nilai sebesar 0.000194 persen.

Guncangan dari financing to deposit ratio sebesar satu standar deviasi pada bulan pertama belum direspon baik terhadap pembiayaan modal kerja maupun pembiayaan investasi BPRS di Indonesia (Gambar 6). Pada bulan selanjutnya pembiayaan modal kerja terus merespon positif guncangan yang terjadi oleh financing to deposit ratio hingga pembiayaan modal kerja mulai stabil pada bulan ke-84 dengan nilai sebesar 0.052618 persen, sedangkan pembiayaan investasi pada bulan selanjutnya terus merespon positif hingga mencapai nilai tertinggi pada bulan ke-3 sebesar 0.003131 persen dan mulai stabil pada bulan ke-9 dengan nilai sebesar 0.000996 persen.
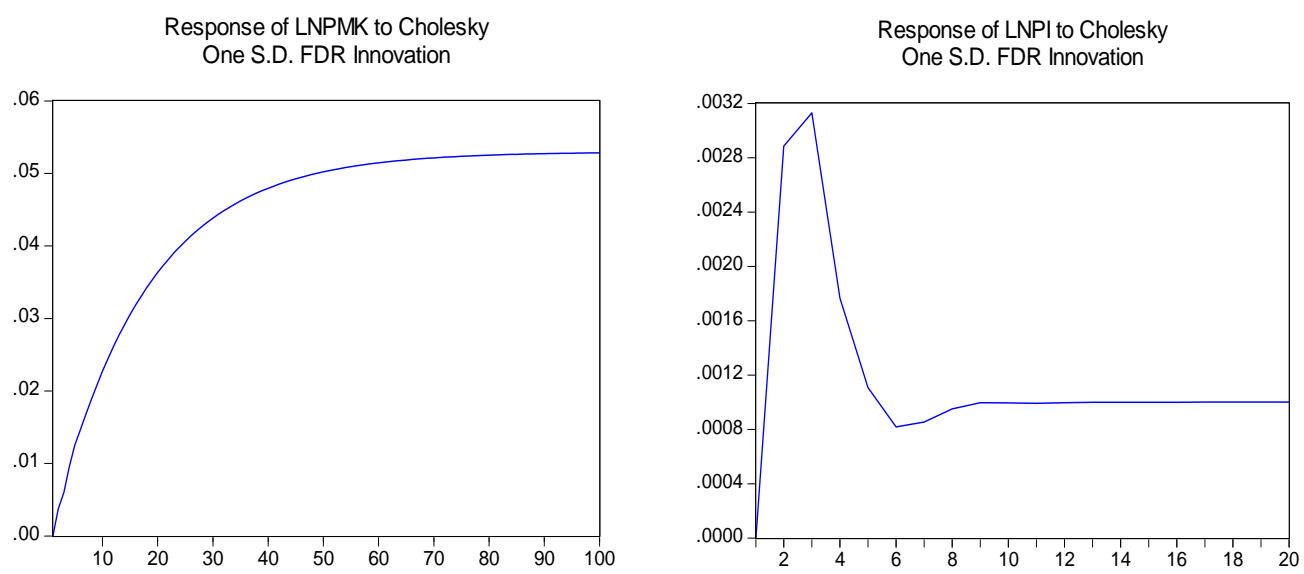

Gambar 6 Respon terhadap guncangan financing to deposit ratio 

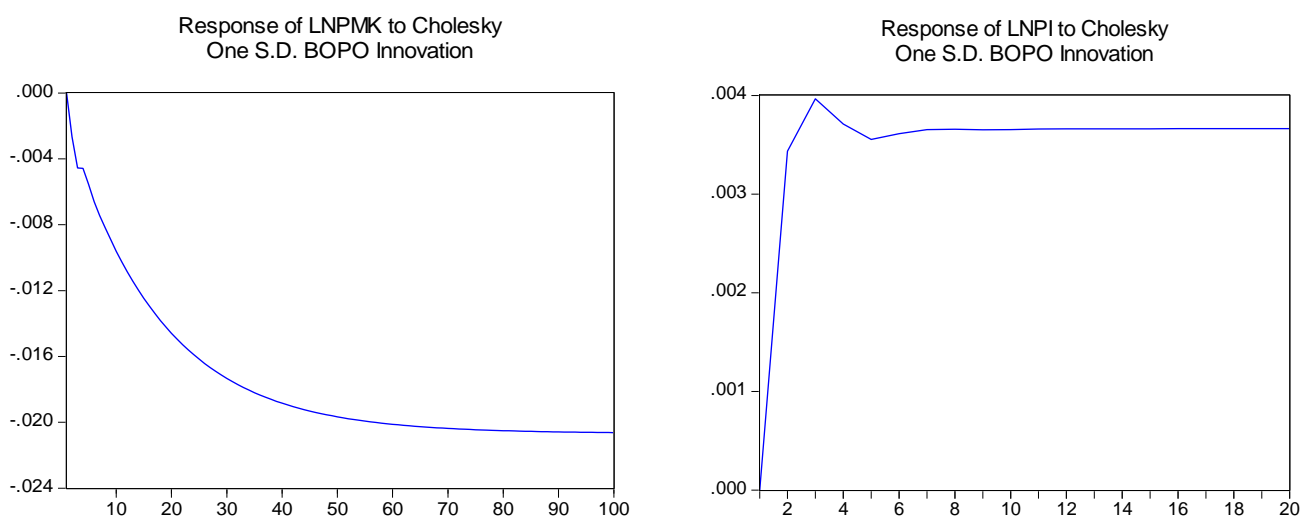

Gambar 7 Respon terhadap guncangan biaya operasional terhadap pendapatan operasional

Guncangan dari biaya operasional terhadap pendapatan opersional sebesar satu standar deviasi pada bulan pertama belum direspon baik terhadap pembiayaan modal kerja maupun pembiayaan investasi BPRS di Indonesia (Gambar 7). Pada bulan selanjutnya pembiayaan modal kerja dan investasi mulai merespon guncangan dengan respon yang berbeda. Pembiayaan modal kerja merespon negatif guncangan sebesar satu standar deviasi pada bulan ke-2 hingga stabil pada bulan ke-89 dengan nilai mencapai 0.020560 persen. Pembiayaan investasi merespon positif guncangan sebesar satu standar deviasi dengan nilai tertinggi pada bulan ke-3 mencapai 0.003966 persen dan stabil pada bulan ke-7 dengan nilai sebesar 0.003653 persen.

Guncangan dari equivalent rate pembiayaan tampak belum direspon pada bulan pertama sebesar satu standar deviasi baik terhadap pembiayaan modal kerja maupun pembiayaan investasi BPRS di Indonesia (Gambar 8). Bulan selanjutnya guncangan equivalent rate pembiayaan baru mulai direspon dengan respon yang positif pada bulan ke-2 sebesar satu standar deviasi dengan nilai mencapai 0.000505 persen oleh pembiayaan modal kerja dan pada bulan-bulan berikutnya merespon negatif hingga stabil pada bulan ke-95 dengan nilai sebesar 0.025916 persen. Pembiayaan investasi pada bulan ke-2 hingga periode terakhir penelitian merespon negatif sebesar satu standar deviasi dengan nilai terendah pada bulan ke-3 mencapai 0.001024 persen dan mulai stabil pada bulan ke-16 dengan nilai sebesar 0.000834 persen.
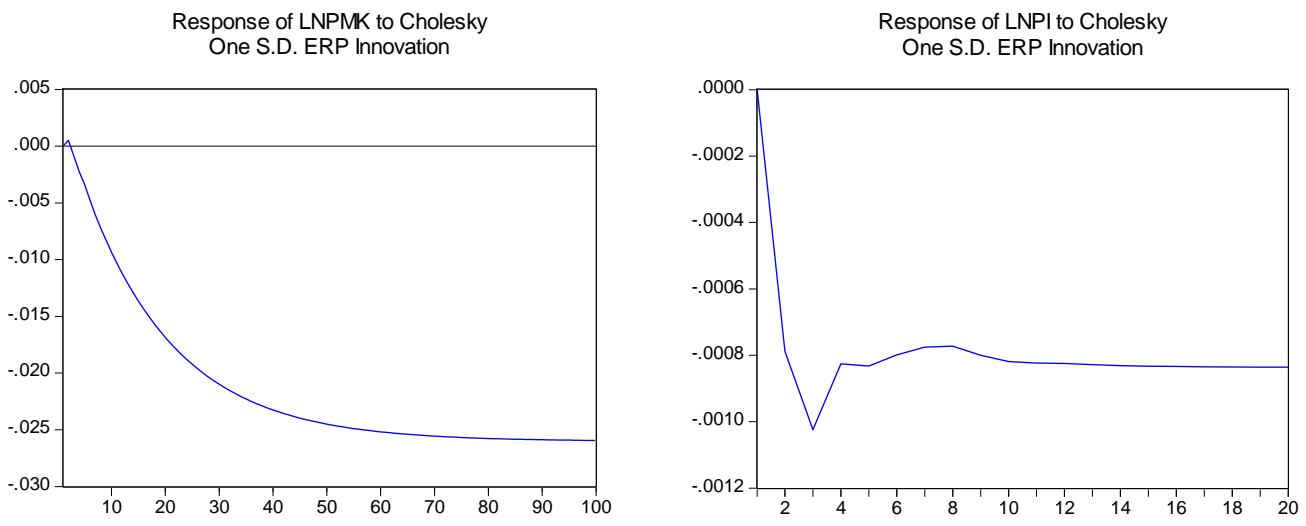

Gambar 8 Respon terhadap guncangan equivalent rate pembiayaan 

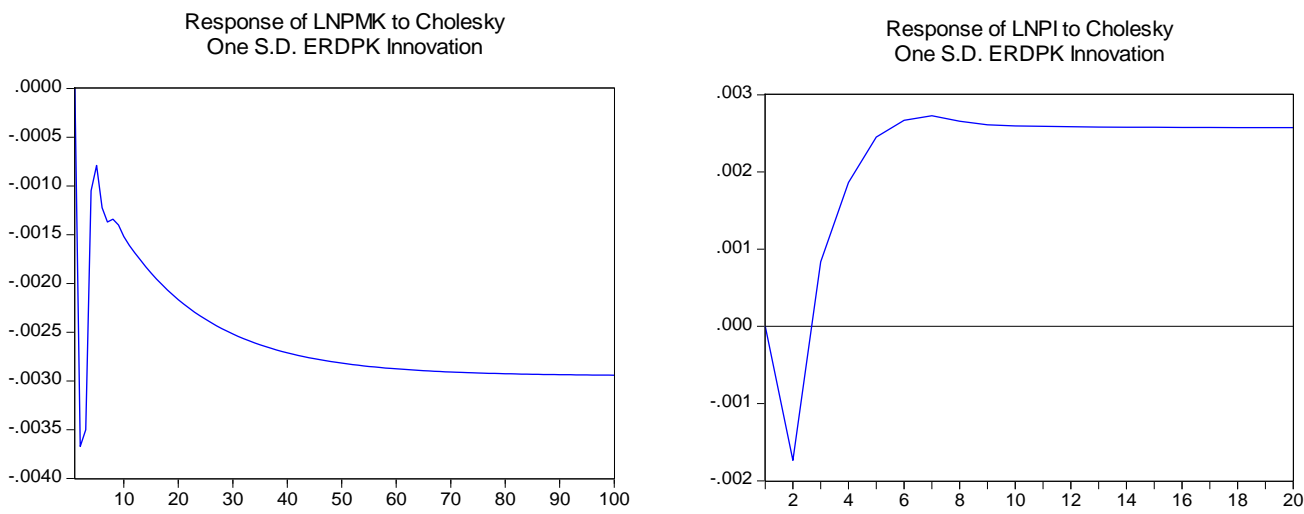

Gambar 9 Respon terhadap guncangan equivalent rate dana pihak ketiga

Guncangan dari equivalent rate dana pihak ketiga belum direspon pada bulan pertama sebesar satu standar deviasi baik terhadap pembiayaan modal kerja maupun pembiayaan investasi BPRS di Indonesia (Gambar 9). Bulan selanjutnya guncangan equivalent rate dana pihak ketiga baru mulai direspon dengan respon yang negatif oleh pembiayaan modal kerja hingga mendapat nilai terendah pada bulan ke- 2 dengan nilai sebesar 0.003673 persen. Nilai respon pembiayaan modal kerja tertinggi terhadap guncangan equivalent rate dana pihak ketiga terjadi pada bulan ke-5 mencapai 0.000790 persen dan respon mulai stabil pada bulan ke-78 dengan nilai sebesar 0.002924 persen. Pembiayaan investasi pada bulan ke-2 merespon negatif hingga mencapai nilai terendah sebesar 0.001736 persen. Pada bulan berikutnya pembiayaan investasi merespon positif dengan nilai tertinggi sebesar 0.002727 persen pada bulan ke-7 dan mulai stabil pada bulan ke-13 dengan nilai sebesar 0.002582 persen.
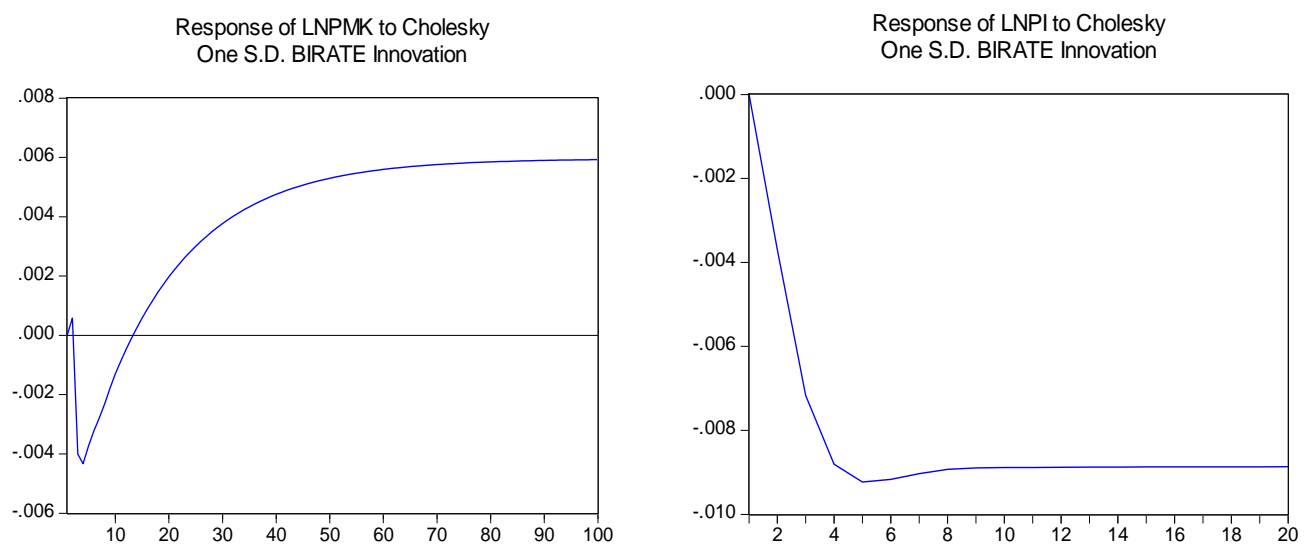

Gambar 10 Respon terhadap guncangan suku bunga Bank Indonesia

Guncangan yang timbul dari BI rate belum direspon pada bulan pertama sebesar satu standar deviasi baik terhadap pembiayaan modal kerja maupun pembiayaan investasi BPRS di Indonesia (Gambar 10). Bulan selanjutnya guncangan BI rate baru mulai direspon positif oleh pembiayaan modal kerja sebesar 0.000580 persen. Pada bulan berikutnya pembiayaan modal kerja merespon negatif sampai mencapai nilai terendah pada bulan ke-4 sebesar 0.004330 persen dan kembali menuju ke respon positif hingga stabil pada bulan ke-84 sebesar 0.005872 persen. Pembiayaan investasi merespon negatif dengan nilai terendah pada bulan ke-5 mencapai 0.009230 persen dan mulai stabil pada bulan ke-9 dengan nilai sebesar 0.008927 persen. 

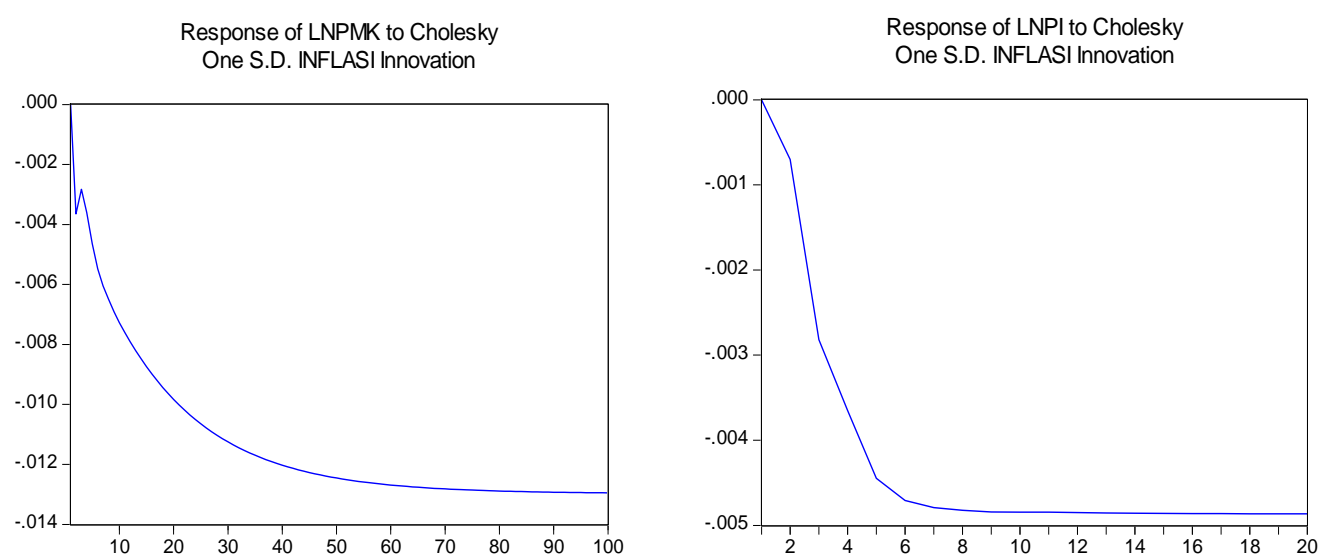

Gambar 11 Respon terhadap guncangan inflasi

Guncangan yang timbul dari inflasi tampak belum direspon pada bulan pertama sebesar satu standar deviasi baik terhadap pembiayaan modal kerja maupun pembiayaan investasi BPRS di Indonesia (Gambar 11). Bulan selanjutnya guncangan inflasi baru mulai direspon dengan respon yang negatif oleh pembiayaan modal kerja dan investasi tersebut. Pembiayaan modal kerja mulai stabil pada bulan ke-90 dengan nilai sebesar 0.012927 persen dan pembiayaan investasi mulai stabil pada bulan ke-9 dengan nilai sebesar 0.004841 persen.

Guncangan yang timbul dari indeks produksi industri belum direspon pada bulan pertama sebesar satu standar deviasi baik terhadap pembiayaan modal kerja maupun pembiayaan investasi BPRS di Indonesia (Gambar 12). Bulan selanjutnya guncangan indeks produksi industri baru mulai direspon dengan respon yang positif oleh pembiayaan modal kerja dengan nilai tertinggi pada bulan ke-4 mencapai 0.003241 persen dan terus berfluktuasi hingga stabil pada bulan ke-85 dengan nilai sebesar 0.002216 persen. Pembiayaan investasi mulai merespon guncangan indeks produksi industri dengan respon negatif dengan nilai terendah pada bulan ke-3 sebesar 0.002946 persen dan terus berfluktuasi hingga stabil pada bulan ke-13 dengan nilai mencapai 0.002652 persen.
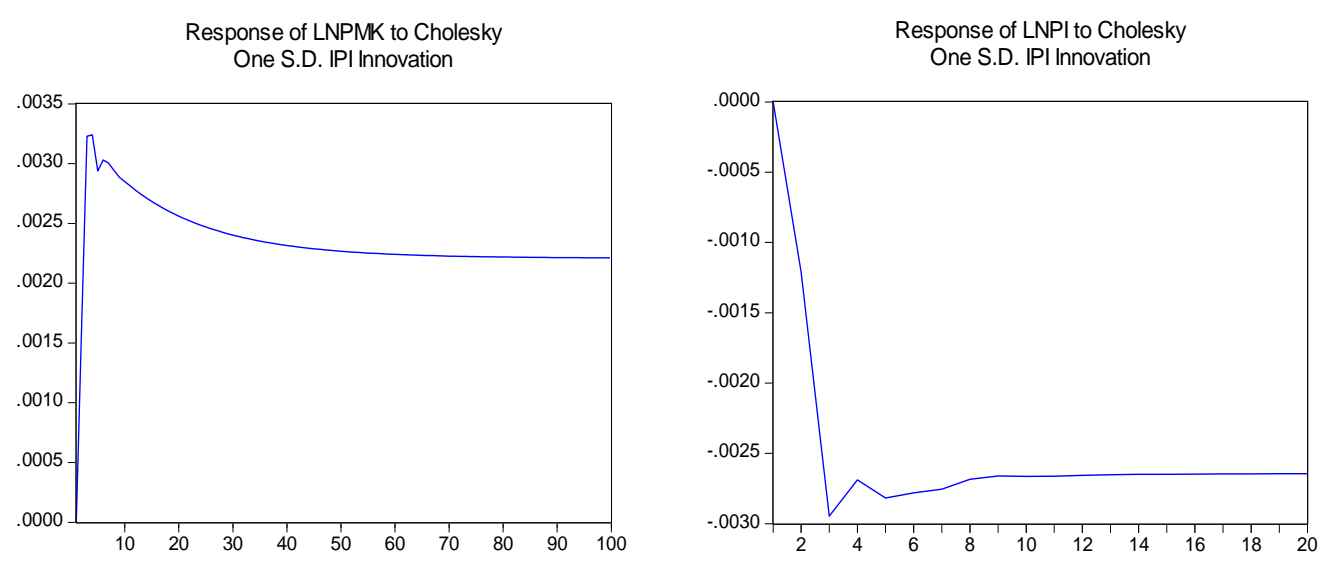

Gambar 12 Respon terhadap guncangan indeks produksi industri 


\section{Hasil Forecasting Error Variance Decomposition (FEVD)}

Analisis FEVD pada penelitian ini bertujuan untuk menjelaskan kontribusi masing-masing variabel dalam menjelaskan keragaman tingkat pembiayaan modal kerja dan investasi BPRS di Indonesia baik variabel kinerja BPRS maupun variabel kondisi makroekonomi. Berikut kontribusi variabelvariabel yang digunakan dalam penelitian ini.

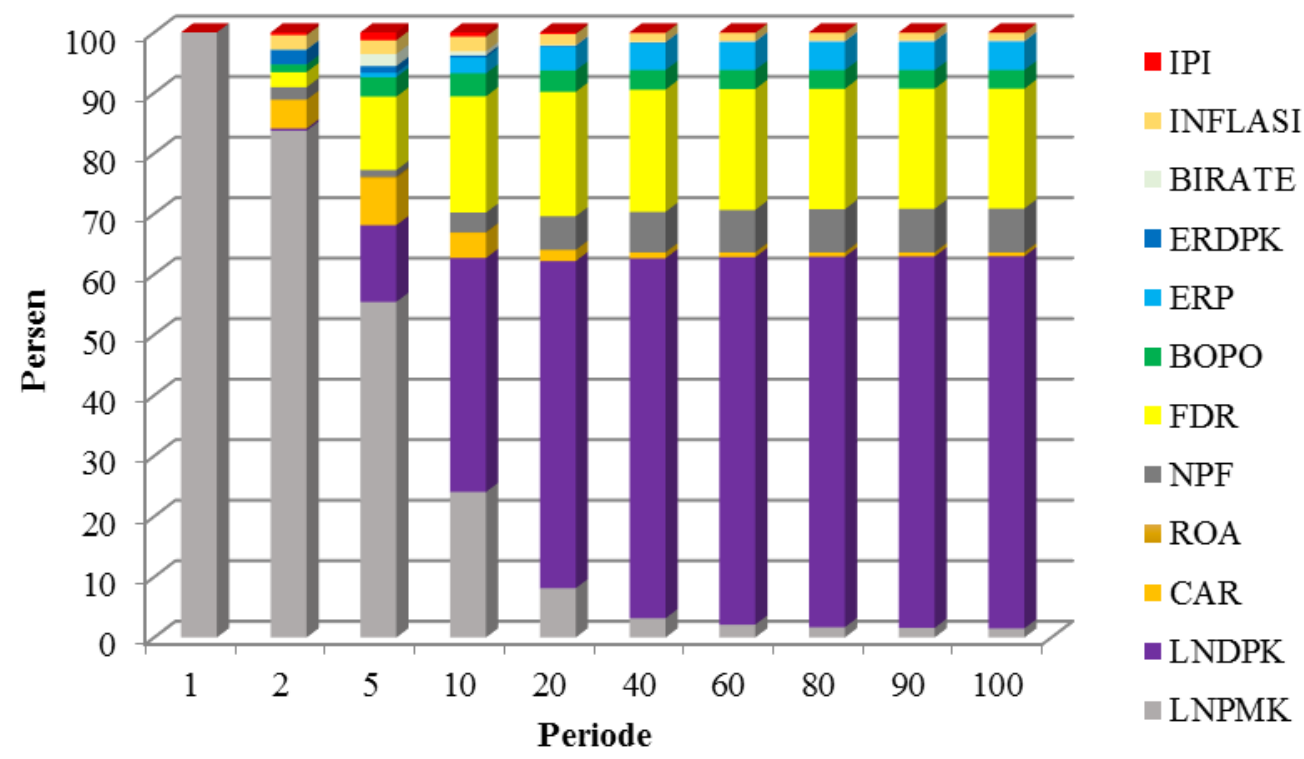

Gambar 13 FEVD pembiayaan modal kerja BPRS di Indonesia

Hasil FEVD menunjukkan bahwa kontribusi terbesar variabel kinerja BPRS dan kondisi makroekonomi dalam menjelaskan keragaman tingkat pembiayaan modal kerja BPRS di Indonesia periode 2011-2015 berasal dari dana pihak ketiga (DPK) dan inflasi. Hal ini mengindikasikan bahwa dana pihak ketiga dan inflasi berkontribusi paling besar menyebabkan terjadinya pembiayaan modal kerja bila dibandingkan dengan variabel lain pada kinerja BPRS dan kondisi makroekonomi. Selain itu, terdapat indikasi dana pihak ketiga dan inflasi secara langsung memengaruhi tingkat pembiayaan modal kerja BPRS di Indonesia.

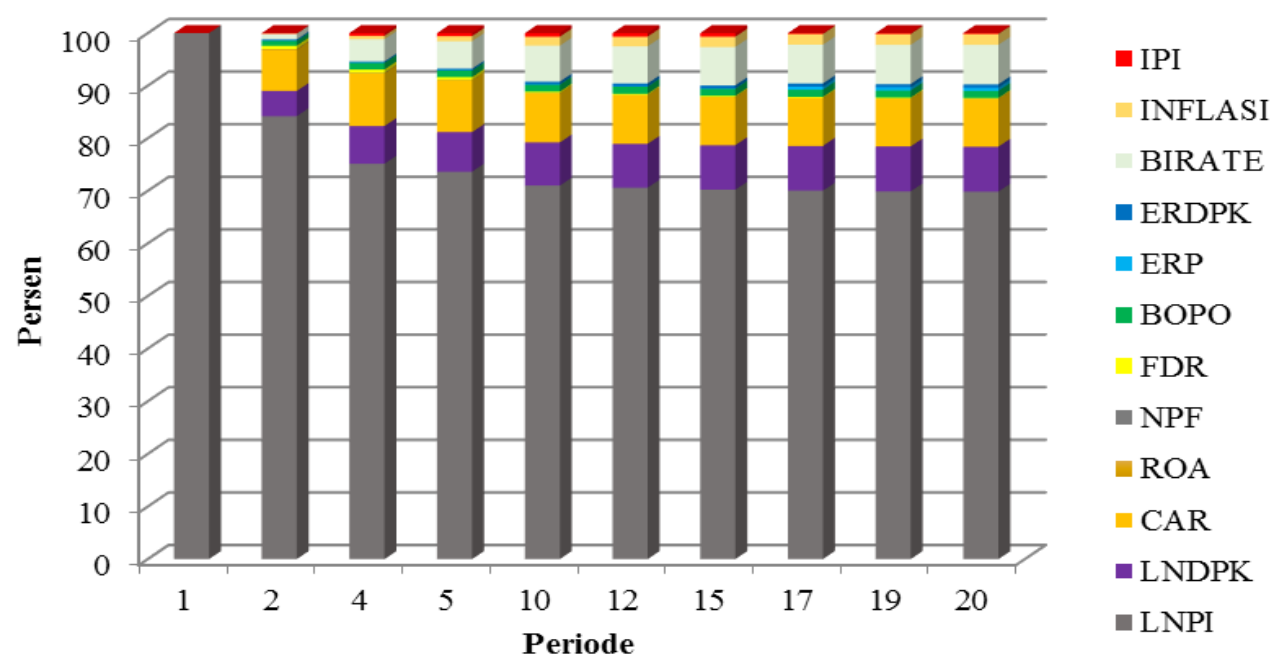

Gambar 14 FEVD pembiayaan investasi BPRS di Indonesia 
Hasil FEVD menunjukkan bahwa kontribusi terbesar variabel kinerja BPRS dan kondisi makroekonomi dalam menjelaskan keragaman tingkat pembiayaan investasi BPRS di Indonesia periode 2011-2015 berasal dari capital adequacy ratio (CAR) dan bi rate. Hal ini mengindikasikan bahwa capital adequacy ratio dan bi rate berkontribusi paling besar menyebabkan terjadinya pembiayaan investasi bila dibandingkan dengan variabel lain pada kinerja BPRS dan kondisi makroekonomi. Selain itu, terdapat indikasi capital adequacy ratio dan bi rate secara langsung memengaruhi tingkat pembiayaan investasi BPRS di Indonesia.

\section{SIMPULAN DAN SARAN}

\section{Simpulan}

Berdasarkan penelitian yang telah dilakukan, maka diperoleh beberapa kesimpulan sebagai berikut:

1. Hasil penelitian ini menunjukkan bahwa pengaruh variabel kinerja BPRS dan kondisi makroekonomi terhadap pembiayaan modal kerja BPRS di Indonesia, yaitu berpengaruh positif dan signifikan pada variabel DPK, FDR, ERDPK, inflasi, dan IPI, sedangkan berpengaruh negatif dan signifikan pada variabel ROA, NPF, BOPO, dan BI rate, dan tidak berpengaruh signifikan pada variabel CAR dan ERP. Pengaruh variabel kinerja BPRS dan kondisi makroekonomi terhadap pembiayaan investasi BPRS di Indonesia, yaitu berpengaruh positif dan signifikan pada variabel DPK, CAR, ROA, FDR, BI rate, dan IPI, sedangkan berpengaruh negatif dan signifikan pada variabel NPF, BOPO, ERP, ERDPK, dan inflasi.

2. Respon pembiayaan modal kerja BPRS terhadap guncangan yang timbul dari variabel kinerja BPRS paling cepat stabil saat terjadi guncangan yaitu variabel capital adequacy ratio (CAR) yang terjadi pada bulan ke-60, sedangkan guncangan yang timbul dari variabel kondisi makroekonomi paling cepat stabil saat terjadi guncangan yaitu variabel BI rate yang terjadi pada bulan ke-84. Respon pembiayaan investasi BPRS terhadap guncangan yang timbul dari variabel kinerja BPRS paling cepat stabil saat terjadi guncangan yaitu variabel biaya operasional terhadap pendapatan operasional (BOPO) yang terjadi pada bulan ke-7, sedangkan guncangan yang timbul dari variabel kondisi makroekonomi paling cepat stabil saat terjadi guncangan yaitu variabel inflasi yang terjadi pada bulan ke-9.

3. Variabel yang membentuk keragaman pada tingkat pembiayaan modal kerja BPRS di Indonesia dengan kontribusi paling besar dijelaskan oleh dana pihak ketiga (DPK) untuk indikator kinerja BPRS dan inflasi untuk indikator kondisi makroekonomi. Pada tingkat pembiayaan investasi BPRS di Indonesia dengan kontribusi paling besar dijelaskan oleh capital adequacy ratio (CAR) untuk indikator kinerja BPRS dan BI rate untuk indikator kondisi makroekonomi.

\section{Saran}

Beberapa hal-hal yang dapat disarankan setelah melakukan penelitian ini adalah:

1. BPRS harus menambah proporsi pembiayaan untuk investasi. Harapannya dengan peningkatan pembiayaan investasi maka nasabah akan memiliki skala usaha yang lebih besar sehingga dalam jangka panjang juga berpengaruh terhadap permintaan pembiayaan pada BPRS.

2. BPRS perlu fokus dalam peningkatan jumlah DPK dengan cara melakukan promosi salah satunya melalui media massa, meningkatkan program CSR seperti pemberian beasiswa, program peduli masyarakat misalnya dengan tema Syariah membawa berkah yang pada intinya menarik minat masyarakat untuk menyimpan dananya di BPRS. Hal ini sesuai dengan hasil estimasi VECM dan FEVD, bahwa dana nasabah memberikan kontribusi terbesar dalam melakukan pembiayaan modal kerja dan investasi BPRS di Indonesia.

3. Penelitian selanjutnya dapat menambahkan periode penelitian dan memperluas cakupan penelitian dengan menggolongkan BPRS berdasarkan wilayah sehingga hasil penelitian lebih 
bervariasi serta memasukkan variabel instrumen moneter yang ada dan menganalisis pembiayaan yang dikhususkan untuk konsumsi.

\section{DAFTAR PUSTAKA}

Antonio, M,S. (2001). Bank Syariah: Dari Teori ke Praktik. Jakarta, Gema Insani Press.

Beik, I,S. \& Aprianti. (2013). Analisis faktor-faktor yang memengaruhi pembiayaan syariah untuk sektor pertanian di Indonesia. Jurnal Agro Ekonomi, 31(1).

[BI] Bank Indonesia. (2011-2015). Statistik Perbankan Indonesia [Internet]. [diunduh 2017 April 12]. Tersedia pada: http://www.bi.go.id.

[BPS] Badan Pusat Statistik. 2011-2015. Berita Resmi Statistik [Internet]. [diunduh 2017 April 08]. Tersedia pada: http://www.bps.go.id.

Carlson, M., Shan, H., \& Warusawitharna, M. (2013). Capital ratios and banking lending: A matched bank approach. Journal Financial Intermediation 22(4), 663-687.

Dendiwijaya, L. (2005). Manajemen Perbankan. Bogor (ID), Ghalia Indonesia.

Fazzari, S.M., \& Petersen, B.C. (1993). Working capital and fixed investment: new evidence on financing constrains. RAND Journal of Economics, 24(3).

Jaya, Y.P., Rindayati, W., \& Ali, M.K. (2015). Analisis faktor-faktor penentu pembiayaan perbankan syariah pada sektor pengangkutan dan komunikasi di Indonesia. Jurnal AlMuzara'ah, 3(1).

Juanda, B. \& Junaidi. (2012). Ekonometrika Deret Waktu: Teori dan Aplikasi. Bogor, IPB Press.

Kashmir. (2008). Manajemen Perbankan. Jakarta, Rajagrafindo Persada.

Kusumawati, N.N. (2013). Analisis pembiayaan sektor konstruksi pada perbankan syariah di Indonesia. Jurnal Al-Muzara'ah, 1(2), 191-203.

Machmud, A. \& Rukmana. (2010). Bank Syariah: Teori, Kebijakan dan Studi Empiris di Indonesia. Jakarta, Erlangga.

Mousa, M.A.B. \& Chedia, H. (2016). Determinants of bank lending: Case of Tunisia. International Journal of Finance and Accounting, 5(1), 27-36. doi:10.5923/j.ijfa.20160501.04.

[OJK] Otoritas Jasa Keuangan. 2011-2015. Statistik Perbankan Syariah [Internet]. [diunduh 2017 April 12]. Tersedia pada: http://www.ojk.go.id.

Sambo, A.O. \& Abdulkadir, A.B. (2015). The continuing influence of common law judges and advocates in the adjudication of Islamic finance disputes in Nigeria. In H A El-Karanshawy et al. (Eds.), Ethics, governance and regulation in Islamic finance. Doha, Bloomsbury Qatar Foundation.

Sari, G.N. (2013). Faktor-faktor yang mempengaruhi penyaluran kredit bank umum di Indonesia (Periode 2008.1-2012.2). Jurnal Riset Ekonomi, Manajemen, Bisnis dan Akutansi 1(3), 931941.

Soemitra, A. (2010) Bank dan Lembaga Keuangan Syariah: Jakarta, Kencana.

Suryadi, G., Priyarsono, D.S., \& Arsyianti, L.D. (2014). Analisis pembiayaan sektor perdagangan hotel dan restoran pada perbankan syariah di Indonesia. Jurnal Al-Muzara'ah, 2(2).

Tanjung, H., Perwaatmadja, \& Karnaen, A. (2007) Bank Syariah: Teori, Praktik, dan Peranannya. Jakarta, Celestial Publishing. 